DIW BERLIN

Discussion

Papers
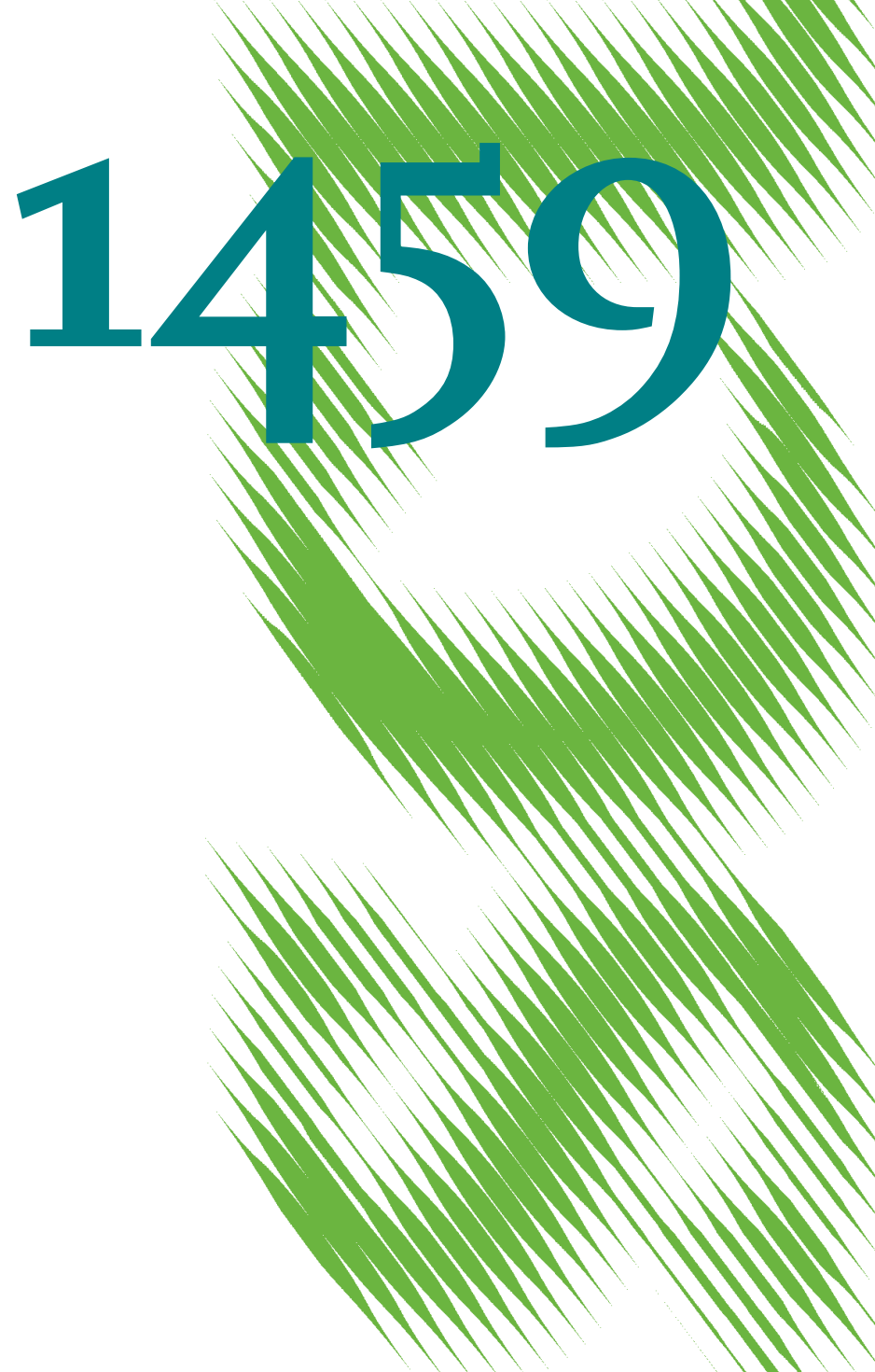

Loan Loss Provision:

Some Empirical Evidence for

Italian Banks

Guglielmo Maria Caporale, Matteo Alessi, Stefano Di Colli and Juan Sergio Lopez 
Opinions expressed in this paper are those of the author(s) and do not necessarily reflect views of the institute.

IMPRESSUM

(C) DIW Berlin, 2015

DIW Berlin

German Institute for Economic Research

Mohrenstr. 58

10117 Berlin

Tel. +49 (30) $89789-0$

Fax +49 (30) $89789-200$

http://www.diw.de

ISSN electronic edition 1619-4535

Papers can be downloaded free of charge from the DIW Berlin website:

http://www.diw.de/discussionpapers

Discussion Papers of DIW Berlin are indexed in RePEc and SSRN:

http://ideas.repec.org/s/diw/diwwpp.html

http://www.ssrn.com/link/DIW-Berlin-German-Inst-Econ-Res.html 


\title{
LOAN LOSS PROVISION: SOME EMPIRICAL EVIDENCE FOR ITALIAN BANKS ${ }^{\S}$
}

\author{
Guglielmo Maria Caporale* \\ Brunel University London, CESifo and DIW Berlin \\ Matteo Alessi \\ Federcasse, Rome \\ Stefano Di Colli \\ Federcasse, Rome and University of Teramo \\ Juan Sergio Lopez \\ Federcasse, Rome
}

March 2015

\begin{abstract}
This paper uses data from a panel of more than 400 Italian banks for the period $2001-2012$ to examine the main determinants of loan loss provision (LLP), which are classified as either discretionary (income smoothing, capital management, signalling) or non-discretionary (related to the business cycle). The results suggest that LLP in Italian banks is driven mainly by non-discretionary components, especially during the recession of 2008-2012, and is consistent with a countercyclical behavior of LLP. Further, it is generally less pro-cyclical (although not during the recent economic crisis) in the case of local banks: since their loans are more collateralised, their behaviour is more strongly affected by supervisory activity, their initial coverage ratio being lower than for other banks.

JEL classification: G21, G28

Keywords: Loan Loss Provision, Bank Lending, Financial System Cyclicality.

*Corresponding author. Research Professor at DIW Berlin.

Email: Guglielmo-Maria.Caporale@brunel.ac.uk

${ }^{\text {s } T h e ~ a u t h o r s ~ a r e ~ g r a t e f u l ~ t o ~ Y i o r g o s ~ A l e x o p o u l o s, ~ C a r l o ~ B o n z a g a, ~ R i c c a r d o ~ D e ~ B o n i s, ~ S i l v i o ~ G o g l i o, ~ P a n u ~ K a l m i, ~}$ Andrea Zaghini and the other participants at the Fourth Euricse International Workshop on "Cooperative Finance and Sustainable Development" and at the Lunch Seminar of the Bank of Italy (20 ${ }^{\text {th }}$ February 2015) for their useful comments and suggestions. The views expressed are those of the authors and do not necessarily reflect those of Federcasse.
\end{abstract}




\section{Introduction}

During the last decade, the Italian economy has experienced one of the deepest recessions of the post-war period. The Italian banking sector was significantly affected by the crisis: bad loans piled up, both reducing revenues and increasing loan loss provisions (LLP, see Figure 1, 2a and 3a), which led to further revenue losses.

The main function of LLP is to cover expected losses; however, it can also be an important tool to pursue other objectives, such as stabilising earnings and dividends over the cycle. Most recently the Bank of Italy has put pressure on the banking industry to assess accurately the quality of loans and to make adequate provision for the increasing credit risk; at present the coverage ratio (the ratio of loan loss reserves to total bad loans, see Figure 2b) appears to be quite different for commercial vis-à-vis local banks (see Figure 3b).

Previous research has highlighted three main drivers of managerial discretionary behaviour: income smoothing, signalling and capital regulation. These factors, together with non-discretionary components and economic fluctuations, determine the provisioning policy of banks. This might also be affected by different approaches to evaluating bad loans (see Dewenter and Hess, 2003): "relationship" banks may have better information on customers than "transactional" banks, and therefore less risky loans (or higher recovery rates). On the other hand, the former may have a stronger incentive to "evergreen” loans compared to the latter. In any case, a "relationship” bank will always have a lower LLP, whether as a result of a correct evaluation of the expected loss or of managerial discretionary behaviour.

This paper uses data from a panel of more than 400 Italian banks for the period $2001-2012$ to examine the main determinants of LLP. In addition to the factors already mentioned, which are commonly considered in the empirical literature, we also analyse the possible effects of guaranteed loans, coverage ratios and the level of risk for the discretionary component. A bank with a higher stock of collateralised loans (a higher coverage ratio, and a lower level of risk) can, in principle, reduce expected future losses, which obviously affects the LLP decision-making process.

The main findings of the analysis are as follows. First, LLP in Italian banks seems to be driven mainly by cyclical and non-discretionary components. Second, although this result holds for local banks as well, LLP for this category of banks is also significantly affected by collateralised loans. This could explain the lower LLP and coverage ratios exhibited in recent years by the Cooperative Credit Banks (CCBs) compared to other categories of banks ${ }^{1}$.

\footnotetext{
${ }^{1}$ The higher level of collateralised loans may be due to the fact that the clients of the CCBs are mainly small and micro enterprises, typically riskier borrowers than large enterprises, households and the public sector.
} 
The paper is organised as follows. Section 2 reviews the literature on the LLP determinants. Section 3 presents the dataset and some preliminary statistics. Section 4 outlines the empirical methodology and discusses the main results. Section 5 offers some concluding remarks.

\section{Literature Review}

There is a huge literature on the linkages between bank lending activity and business cycles. A recent strand has focused on how provisions contribute to the pro-cyclicality of the financial sector, being lower when output and credit are expanding and higher when they are contracting. LLP is also related to credit and business cycle fluctuations because during economic booms and downturns credit risk might be incorrectly assessed. Asea and Blomberg (1998), using data on US banks from 1977 to 1993, show that bank lending is cyclical and affects aggregate economic activity. The same conclusions are reached by Gambacorta and Mistrulli (2004), Gambacorta (2005), Di Giulio (2010), Di Colli and Girardi (2011) for the Italian banking sector. Other studies, including Bikker (2004), Peek, Rosengren and Tootell (2003) and Lown and Morgan (2006), provide evidence of a relationship between lending activity and several cyclical variables, such as GDP growth, inflation and monetary factors.

Various papers using US data find a positive correlation between loan growth and changes in bank capital requirements (Bernanke and Lown, 1991; Hancock and Wilcox, 1998; Peek and Rosengren, 1995; Brinkmann and Horwitz, 1995). Kashyap and Stein (2000) and Kishan and Opiela (2000) report that the impact of the lending channel in the US banking sector is greater for banks with less liquid assets and less capital. Similar but less conclusive results are obtained for European banks by Altunbas et al. (2002) and Ehrmann et al. (2003). Chami and Cosimano (2001), Zicchino (2005) and Furfine (2001) instead focus on the impact of capital requirement on both macroeconomic and regulatory variables.

Bank lending fluctuations over the business cycle could also depend on a wrong perception of credit risk. Banks are more likely to expand credit supply during an economic boom, while during a recession or a cyclical downturn they are more risk-averse (Berger and Udell, 2003). Caporale, Di Colli and Lopez (2014) show that there was a bad loans surplus (a higher level than implied by their macroeconomic and financial determinants) during the 2008-2009 and 2011-2012 recessions in Italy, and also that it can be partially explained by the lending policy adopted during good times.

The business cycle could also have an impact on the non-discretionary components in backward-looking provisioning systems. According to Whalen (1994) and Beaver and Engle (1996), LLP is related to contemporary loans, while Bikker and Metzemakers (2005) find that the 
ratio of LLP to total loans is linked to the business cycle. Some studies report a time-lag between riskier loans which are granted during economic boom and LLP in the following downturn, which follows backward-looking rules (Keeton, 1999; Jiménez and Saurina, 2005; Caporale et al., 2014).

LLP can also be affected by discretionary components, such as income smoothing. This can be defined as a practice aiming at the reduction of variability of net profit over time. In other words, managers will increase (decrease) LLP when earnings are high (low) in order to stabilise net profit. Bank managers might have significant incentives to adopt income smoothing procedures: adjusting a bank's current performance to a firm-specific mean (Collins et al, 1995), allowing managers to ensure a steady flow of dividends to bank stockholders, improving the risk perception that regulators have about the bank, keeping a bank’s stock price stable by reducing earnings volatility. Managerial self-interest incentives could also lead to income smoothing, with the aim of stabilising over time managers' compensation, and minimising the probability of being fired (Fudenberg and Tirole, 1995).

Furthermore, regulators are interested in reducing banks' pro-cyclical behaviour, and therefore an increase in loan loss reserves during good times, from which to draw when the economy slows down. Greenawalt and Sinkey (1988) find that regional banks are more likely to exhibit income smoothing behaviour, while Ma (1988) shows that US commercial banks used LLP to smooth earnings, whilst there is no relationship between LLP and loan portfolio quality. Collins et al. (1995) also find a positive relationship between earnings management and LLPs, thus supporting the notion that banks smooth income over time to a firm-specific mean. More recently, Anandarajan et al. (2007) show that Australian commercial banks are engaged in earnings management practices, especially if they are publicly traded. Fonseca and Gonzàlez (2008) in their multi-country study find that the incentive to smooth earnings is positively related to developed and market-oriented financial systems, but negatively related to banking systems characterised by higher levels of accounting disclosure, a supervisory framework, and more restrictions on banking activities.

Banks can also decide on provision levels to meet capital requirements and avoid the costs resulting from non-compliance; a higher level of provisions, when capital is low, can be used to build up a strong reserve buffer. The evidence on this linkage, though, is mixed. Some empirical studies do not find a significant impact of capital on LLP (Davis and Zhu, 2009; Craig, 2006), whilst other report either a positive (Collins et al., 1995) or a negative relationship (Moyer, 1990) and Beatty et al., 1995). LLP could be also used to signal financial strength; specifically financial markets could perceive a higher level of provisions as a signal that bank managers have a positive view on future cash flows after taking into account unexpected changes in non-performing loans. In 
other words, an unexpected increase in LLP could be viewed as positive news for future earnings, instead of an anticipated future deterioration of the credit portfolio's quality. However, the empirical evidence is again mixed. Liu, Ryan and Wahlen (1997) claim that the market interprets higher discretionary LLP as good news only if banks appear to experience default risk problems. In contrast, Ahmed et al. (1999) do not find any evidence of signalling behaviour.

\section{Data and Descriptive Analysis}

\subsection{Data Sources and Definitions}

As mentioned above, the existing literature suggests that LLP could be affected by at least three factors, i.e. the economic cycle, and both the non-discretionary and discretionary behaviour of bank managers. The non-discretionary component is related to credit risk and its aim is to cover expected future credit losses on loans (Whalen, 1994; Beaver and Engle 1996). During recessions, non-performing loans and defaults on loans are typically high; as a result, LLPs increase. On the other hand, during economic booms firms and households are less likely to become insolvent, and fewer problem loans are identified by banks and supervisory authorities. Therefore, the nondiscretionary components affect LLP countercyclically, and consequently bank earnings and capital; in fact Laeven and Majnoni (2003) and Bikker and Metzemakers (2005) showed that the ratio of LLP to total assets exhibits strong cyclicality.

Several indicators have been used to capture the non-discretionary components of LLP. Following Ahmed et al. (1999), Bouvatier and Lepetit (2008), Soerdamono et al. (2012) and Bouvatier et al. (2014), we consider the ratio of non-performing loans to total loans $\left(N P L_{i, t}\right)$. Furthermore, we incorporate a measure of the expected credit risk defined as the rate of change in the ratio of non-performing loans to total loans $\left(D N P L_{i, t}\right)$. In particular, $D N P L_{i, t}$ is calculated as follows: $D N P L_{i, t}=\left(N P L_{i, t+1}-N P L_{i, t}\right)$. Both of these variables are expected to have a positive effect on LLP, since they are a function of the expected credit risk. Finally, the ratio of total loans to total assets $\left(L O A N_{i, t}\right)$ is included as another non-discretionary component. $L O A N_{i, t}$ is also expected to have a positive relationship with LLP, since loan growth is one of the sources of bank credit risk. The growth rate of real per capita gross domestic product $\left(G D P G_{t}\right)$ is also included to capture the procyclicality of LLP. Further, since our sample period includes the global financial crisis and the Italian double-dip recession, a switch dummy $\left(\right.$ CRISIS $\left._{t}\right)$ equal to 1 from 2008 to 2012 (0 otherwise) is added.

We then consider three possible discretionary components reflecting capital management, income smoothing and signalling. According to the capital management hypothesis, LLP reduces Tier 1 capital and is deducted from risk-weighted assets when calculating Tier 2 capital. If the 
increase of Tier 2 capital associated with a higher level of LLPs is larger than the decrease in Tier 1 capital, discretionary behaviour could lead to an increase in regulatory capital without a corresponding reduction in the insolvency risk (regulatory capital arbitrage). As a result, less capitalised banks are expected to be less willing to make LLP. This is most commonly tested by using the deviation of the Total Capital Ratio from $8 \%$, divided by $8 \%\left(C A P_{i, t}\right)$, as in Bouvatier and Lepetit (2008) and Bouvatier et al. (2014), or the simple ratio of total equity to total assets, as in Bikker and Metzemakers (2005) and Soedarmono et al. (2012). We use a dummy variable (CAP $\left.P_{i, t}\right)$ which is equal to 1 if the bank has a Tier 1 ratio greater than that for the 75 th percentile of the distribution of the full sample of banks, 0 otherwise.

The income smoothing hypothesis implies that banks should decrease (increase) LLP when earnings are expected to be low (high). The coefficient sign on earnings could be either positive or negative: if banks use provisions to smooth earnings, the expected sign is positive; however, a negative sign is also possible owing to pro-cyclical effects. This hypothesis is tested using the ratio of earnings before interest, taxes and LLP to total assets $\left(I S_{i, t}\right)$, as in Anandarajan et al. (2006), Bouvatier and Lepetit (2008), Soerdamono et al. (2012), and Bouvatier et al. (2014). Finally, banks can use LLP to signal their financial strength (Ahmed et al., 1999; Kanagaretnam et al., 2005). To test this hypothesis, we use the one-year-ahead change of earnings before taxes $\left(S I G N_{i, t}=I S_{i, t+1}\right.$ $I S_{i, t} / I S_{i, t}$ ), an adjusted version of the weighted one considered by Anandarajan et al. (2006), Bouvatier and Lepetit (2008) Soedarmono et al. (2012) and Bouvatier et al. (2014).

The full list of variables and their sources is shown in Table 1. The sample is an unbalanced panel of Italian banks' balance sheets and income statements from 2001 to 2012. The data have been obtained from the Italian Banking Association (ABI) balance sheet database and ISTAT. We focus on commercial banks, and therefore have left out investment and trust corporations, and consumer credit and finance companies. We have also dropped banks with less than 7 consecutive observations. Table 2 shows the total number of banks in the selected sample, by year and by category. Local banks represent approximately 80 percent of the banks in our dataset.

\subsection{Descriptive Statistics}

The double-dip recession experienced by the Italian economy between 2008 and 2012 had a significant effect on credit risk: from 2008, the annual rate of growth of LLP for all the banks in our sample increased from $8.3 \%$ to more than 15\%. Figure 2a shows that the ratio of LLP to total loans almost doubled, from 2.1\% in 2008 to 3.7\% in 2012. Figure 2b plots the average coverage ratio (the ratio of LLPs to bad loans), which peaked at 56.6\% in 2006 before starting to decline during the 
global financial crisis. Figures 3a - 3b show that local banks (proxied by the CCBs) experienced, on average, a lower ratio of LLP to total loans than the full sample of banks. The growth rate of this ratio went up from $1.4 \%$ in 2008 to $2.8 \%$ in 2012. As in the case of other credit institutions, the coverage ratio of local banks started to decrease in 2007, after peaking at 54.9\% in in 2006. Throughtout the sample it is lower than for all banks.

Some descriptive statistics are reported in Table 3. The ratio of LLP to bad loans is on average $1.3 \%$ of total assets, whilst bad loans represent about $4.4 \%$ of total loans. Loans are the main asset (64.9\% of total assets). The ratio of earnings before interest, taxes and LLP to total assets is, on average, positive and equal to $0.8 \%$, while its one-year-ahead percentage rate of change $\left(S I G N_{i, t}\right)$ indicates that future earnings were expected to decline.

We also clustered the banks according to several criteria. First of all, the sample was split according to bank size. Cluster 1 (Big Size) contains banks with a level of total assets greater than for the $75^{\text {th }}$ percentile of the sample distribution, while banks with a level of total assets lower than this threshold are in Cluster 2 (Low Size). Table 3 suggests that bigger banks have higher LLP (1.49\%) and $L O A N_{i, t}$ but a lower $N P L_{i, t}$. A second classification criterion is given by the guarantee scheme: the sample was divided into two groups (Cluster 3 and 4) on the basis of the ratio between collateralised loans and total loans; Cluster 3 (High Guarantees) includes all the banks with a percentage of guaranteed loans greater than that for the $75^{\text {th }}$ percentile of the sample distribution, and Cluster 4 the remaining ones. Banks with a higher level of guarantees, on average, have higher LLP and bad loans as a percentage of total loans. Finally, banks were also divided between High and Low Risk ${ }^{2}$ banks (Cluster 5 and 6), and banks with a High or Low Coverage Ratio (Cluster 7 and 8). An interesting feature is that riskier banks have a higher percentage of loans relative to total assets. They also have a higher ratio of LLP to total assets (1.6\%) and pessimistic expectations about future profitability ( $S I G N_{i, t}$, is on average $\left.-57.4 \%\right)$.

Table 4 focuses on local banks. These are clustered in eight groups using the same criteria as in Table 3. It can be seen that they have lower LLP (1.3\%) and $L O A N_{i, t}(64.1 \%)$ than all banks. Interestingly, local banks in Cluster 1 (Big Size), Cluster 4 (Low Guarantees) and Cluster 8 (Low Coverage Ratio) have a low ratio of LLP to total assets, close to $1.0 \%$.

\footnotetext{
${ }^{2}$ Risk is defined as the standard deviation of the adjusted return on equity (ROE), computed with three-year rolling windows.
} 


\section{Econometric Analysis}

\subsection{The Baseline Regression}

The determinants of LLP in Italian banks are analysed following a similar approach to Bouvatier and Lepetit (2008), Soerdamono et al. (2012), Packer and Zhu (2012), and Bouvatier et al. (2014). The model is specified as follows:

$$
\begin{aligned}
L L P_{i, t}= & \beta_{0}+\beta_{1} L L P_{i, t-1}+\beta_{2} N P L_{i, t}+\beta_{3} \Delta N P L_{i, t}+\beta_{4} \operatorname{LOAN}_{i, t}+\beta_{5} \Delta G D P_{t}+\beta_{6} \text { CRISIS }_{t}+ \\
& +\beta_{7} \Delta G D P_{t} \cdot C R I S I S_{t}+\beta_{8} I S_{i, t}+\beta_{9} C A P_{i, t}+\delta_{t}+\varepsilon_{i, t}
\end{aligned}
$$

where the dependent variable $\left(L L P_{i, t}\right)$ is the ratio of LLP to total assets for bank $i$ and year $t, N P L_{i, t}$ is the ratio of non-performing loans to total loans, $\Delta G D P_{t}$ is the annual rate of change of Italian GDP, CRISIS $_{t}$ is a dummy variable equal to 1 for the years 2008-2012 and 0 otherwise, $I S_{i, t}$ is the ratio of earnings before interest, taxes and LLP to total assets, CAP $P_{i, t}$ is a capital management variable, as previously defined. The estimation method is the generalized method of moments (GMM) with regressions in first differences (see Arellano and Bond, 1991), using a two-step estimator robust to heteroscedasticity. Fixed effects are included in the specification. The GMM instruments are only used for the lagged dependent variable $\left(L L P_{i, t-1}\right)$, whilst the other variables are treated as strictly exogenous. A robust $\mathrm{AR}(2)$ test for the absence of second-order serial correlation in the first-difference residuals is carried out.

The results are shown in Table 5 . The coefficient on $I S_{i, t}$ is negative and statistically significant, which implies a rejection of the null that Italian banks use discretionary provisions to smooth their income. In other words, they tend to behave cyclically and to reduce LLP when the economy is performing well and earnings before taxes and LLP are increasing. $C A P_{i, t}$ is positively linked to $L L P_{i, t}$ but its coefficient is small and only significant at the $10 \%$ level, suggesting that capital management does not play an important role. The coefficient on $N P L_{i, t}$ is positive as expected, and so is that on the loan to assets ratio, suggesting that LLP increases when credit risk is higher, consistently with the previous empirical literature.

Finally, the business cycle affects LLP in a nonlinear way, which reflects the double-dip recession of 2008-2012. The negative and statistically significant coefficient for $\triangle G D P_{i, t}$ suggests the presence of countercyclical components in LLP behaviour, especially during periods of economic growth. This is in line with other studies (e.g., Soerdamono et al., 2012). During expansionary phases, as for instance 2001-2007, LLP appears to be driven mainly by microeconomic, bank-specific factors. As for macroeconomic factors, during good times banks might be forward-looking and make relatively high provisions; if there is a downturn, LLP is pushed up by the higher credit risk. This is clearly shown by the positive and statistically significant 
coefficient on CRISIS $_{t}$, as well as the interactive dummy, $\Delta G D P_{t} \cdot C R I S I S_{t}$, whose coefficient is negative and statically significant. To model nonlinearities, we introduce in Equ. (2) and (3) two more interactive dummies for the income smoothing hypothesis (IS $S_{i, t} \cdot \operatorname{CRISIS}_{t}$ and $I S_{i, t}$. NOCRISIS $_{t}$ ), where NOCRISIS ${ }_{t}$ is equal to 1 for the years 2001-2007, 0 otherwise:

$$
\begin{aligned}
& L L P_{i, t}=\beta_{0}+\beta_{1} L L P_{i, t-1}+\beta_{2} N P L_{i, t}+\beta_{3} \Delta N P L_{i, t}+\beta_{4} L O A N_{i, t}+\beta_{5} \Delta G D P_{t}+\beta_{6} \text { CRISIS }_{t}+ \\
& +\beta_{7} \Delta \text { GDP }_{t} \cdot \text { CRISIS }_{t}+\beta_{8} \text { IS }_{i, t} \cdot \text { CRISIS }_{t}+\beta_{9} \text { CAP }_{i, t}+\delta_{t}+\varepsilon_{i, t} \\
& L L P_{i, t}=\beta_{0}+\beta_{1} L L P_{i, t-1}+\beta_{2} N P L_{i, t}+\beta_{3} \Delta N P L_{i, t}+\beta_{4} L O A N_{i, t}+\beta_{5} \Delta G D P_{t}+\beta_{6} \text { CRISIS }_{t}+ \\
& +\beta_{7} \text { CRISIS }_{t}+\beta_{8} \Delta \text { GDP }_{t} \cdot \text { CRISIS }_{t}+\beta_{9} \text { IS }_{i, t} \cdot \text { NOCRISIS }_{t}+\beta_{10} \text { CAP }_{i, t}+\delta_{t}+\varepsilon_{i, t}
\end{aligned}
$$

The estimation results (see Table 5) imply a rejection of the income smoothing hypothesis for both subsamples (2001-2007 and 2008-2012), which confirms the countercyclical behaviour of LLP. Of the two interactive dummy coefficients only that on $\mathrm{IS}_{i t} \cdot \mathrm{CRISISt}_{i, t}$ is statistically significant. Again, cyclicality in LLP is mainly due to the behaviour of Italian banks during the crisis.

To test signalling behaviour, the baseline specification is expanded by adding $S I G N_{i, t}$ as in Equation (4):

$$
\begin{aligned}
L L P_{i, t}= & \beta_{0}+\beta_{1} L L P_{i, t-1}+\beta_{2} N P L_{i, t}+\beta_{3} \Delta N P L_{i, t}+\beta_{4} L O A N_{i, t}+\beta_{5} \Delta G D P_{t}+\beta_{6} \text { CRISIS }_{t}+ \\
& +\beta_{7} \Delta G D P_{t} \cdot \text { CRISIS }_{t}+\beta_{8} \operatorname{CAP}_{i, t}+\beta_{9} \operatorname{SIGN}_{i, t}+\delta_{t}+\varepsilon_{i, t}
\end{aligned}
$$

The coefficient on $S I G N_{i, t}$ is close to 0 and insignificant, which implies a rejection of the signalling hypothesis for Italian banks, consistenly with the findings of Soerdamono et al. (2012) and Bouvatier et al. (2014).

\subsection{Testing for Other Effects}

Other interactive dummies are added to the baseline specification given by Equation (1) to examine further issues in the LLP behaviour of Italian banks. The first is the possible presence of a size effect in income smoothing behaviour. For this purpose banks with Total Assets greater than that for the $75^{\text {th }}$ percentile of the sample distribution are classified as big banks. A dummy variable, $H S I Z E_{i, t}$, is then defined as being equal to 1 for big banks, and 0 otherwise. LSIZE $E_{i, t}$ is instead equal to 1 when $H S I Z E_{i, t}$ is equal to 0, and 0 otherwise. Equations (5.1) and (5.2) include the dummies $H_{S I Z E_{i, t}}$ and $L_{S I Z E_{i, t}}$ interacted respectively with $I S_{i, t}$ and $I S_{i, t}$ jointly with both $C R I S I S_{t}$ and NOCRISIS $_{t}$

$$
\begin{aligned}
L L P_{i, t}= & \beta_{0}+\beta_{1} L L P_{i, t-1}+\beta_{2} N P L_{i, t}+\beta_{3} \Delta N P L_{i, t}+\beta_{4} \operatorname{LOAN}_{i, t}+\beta_{5} \Delta G D P_{t}+\beta_{6} \text { CRISIS }_{t}+ \\
& +\beta_{7} \Delta G D P_{t} \cdot \text { CRISIS }_{t}+\beta_{8} \operatorname{SIZE}_{i, t}^{H, L} \cdot I_{i, t}+\beta_{9} \operatorname{CAP}_{i, t}+\delta_{t}+\varepsilon_{i, t}
\end{aligned}
$$




$$
\begin{aligned}
L L P_{i, t}= & \beta_{0}+\beta_{1} L L P_{i, t-1}+\beta_{2} N P L_{i, t}+\beta_{3} \Delta N P L_{i, t}+\beta_{4} \operatorname{LOAN}_{i, t}+\beta_{5} \Delta G D P_{t}+\beta_{6} \operatorname{CRISIS~}_{t}+ \\
& +\beta_{7} \Delta G D P_{t} \cdot \operatorname{CRISIS}_{t}+\beta_{8} \operatorname{SIZE}_{i, t}^{H, L} \cdot I_{i, t} \cdot \operatorname{CRISIS}_{t}+\beta_{9} \operatorname{CAP}_{i, t}+\delta_{t}+\varepsilon_{i, t} \\
L L P_{i, t}= & \beta_{0}+\beta_{1} L L P_{i, t-1}+\beta_{2} N P L_{i, t}+\beta_{3} \Delta N P L_{i, t}+\beta_{4} \operatorname{LOAN}_{i, t}+\beta_{5} \Delta G D P_{t}+\beta_{6} \operatorname{CRISIS~}_{t}+ \\
& +\beta_{7} \Delta G D P_{t} \cdot \operatorname{CRISIS}_{t}+\beta_{8} \operatorname{SIZE}_{i, t}^{H, L} \cdot \operatorname{IS}_{i, t} \cdot \operatorname{NOCRISIS~}_{t}+\beta_{9} \operatorname{CAP}_{i, t}+\delta_{t}+\varepsilon_{i, t}
\end{aligned}
$$

where $\operatorname{SIZE}_{i, t}^{H, L}$ is alternatively $\operatorname{HSIZE}_{i, t}$ or $L S I Z E_{i, t}$.

The results in Table 6 (for $H_{S I Z E}$ ) and in Table 7 (for $L S I Z E_{i, t}$ ) provide evidence of a size effect: the cyclical behaviour of LLP (negative coefficient) is confirmed for small Italian banks, and only during the crisis.

To examine the role of guarantees we define a dummy variable, $H G U A_{i, t}$, which takes value 1 if the ratio of guaranteed loans to total loans is greater than that for the $75^{\text {th }}$ percentile of the sample distribution, and 0 otherwise. $L G U A_{i, t}$ is instead defined as being equal to 1 when $H G U A_{i, t}$ is equal to 0 , and 0 otherwise. Equations (6.1), (6.2) and (6.3) include respectively the dummies $H G U A_{i, t}$ and $L G U A_{i, t}$ and then the same dummies interacted in turn with $I S_{i, t}$ and with $I S_{i, t}$ jointly with both CRISIS $_{t}$ and NOCRISIS . $_{\text {. }}$

$$
\begin{aligned}
L L P_{i, t}= & \beta_{0}+\beta_{1} L L P_{i, t-1}+\beta_{2} N P L_{i, t}+\beta_{3} \Delta N P L_{i, t}+\beta_{4} \operatorname{LOAN}_{i, t}+\beta_{5} \Delta G D P_{t}+\beta_{6} \operatorname{CRISIS}_{t}+ \\
& +\beta_{7} \Delta G D P_{t} \cdot \operatorname{CRISIS}_{t}+\beta_{8} G U A_{i, t}^{H, L} \cdot I_{i, t}+\beta_{9} \operatorname{CAP}_{i, t}+\delta_{t}+\varepsilon_{i, t} \\
L L P_{i, t}= & \beta_{0}+\beta_{1} L L P_{i, t-1}+\beta_{2} N P L_{i, t}+\beta_{3} \Delta N P L_{i, t}+\beta_{4} \operatorname{LOAN}_{i, t}+\beta_{5} \Delta G D P_{t}+\beta_{6} \operatorname{CRISIS}_{t}+ \\
& +\beta_{7} \Delta G D P_{t} \cdot \operatorname{CRISIS}_{t}+\beta_{8} G U A_{i, t}^{H L} \cdot I_{i, t} \cdot \operatorname{CRISIS}_{t}+\beta_{9} \operatorname{CAP}_{i, t}+\delta_{t}+\varepsilon_{i, t} \\
L L P_{i, t}= & \beta_{0}+\beta_{1} L L P_{i, t-1}+\beta_{2} N P L_{i, t}+\beta_{3} \Delta N P L_{i, t}+\beta_{4} \operatorname{LOAN}_{i, t}+\beta_{5} \Delta G D P_{t}+\beta_{6} \operatorname{CRISIS}_{t}+ \\
& +\beta_{7} \Delta G D P_{t} \cdot \operatorname{CRISIS}_{t}+\beta_{8} G U A_{i, t}^{H, L} \cdot I_{i, t} \cdot \operatorname{NOCRISIS}_{t}+\beta_{9} \operatorname{CAP}_{i, t}+\delta_{t}+\varepsilon_{i, t}
\end{aligned}
$$

where $G U A_{i, t}^{H, L}$ is alternatively $H G U A_{i, t}$ or $L G U A_{i, t}$.

The results in Table 8 (for $H G U A_{i, t}$ ) and in Table 9 (for $L G U A_{i, t}$ ) confirm that the cyclical behaviour (negative coefficient) of LLP only characterises banks with a better guaranteed credit portfolio, particularly during the crisis.

LLP could also be affected by the coverage ratio (CR) of non-performing loans. In fact, an appropriate CR is a requirement imposed by the Italian banking supervisor (the Bank of Italy). As shown by Fonseca and Gonzalez (2008) and Bouvatier et al. (2014), income smoothing is lower in countries where the supervisor has greater powers. Therefore, one should expect stronger cyclicality of LLP in banks with a lower CR. To examine this issue we define a dummy variable $H C R_{i, t}$ which takes value 1 if the $\mathrm{CR}$ (ratio of loan loss provisions over non-performing loans) is greater than that for the $75^{\text {th }}$ percentile of the sample distribution and 0 otherwise. $L C R_{i, t}$ is instead equal to 1 when 
$H C R_{i, t}$ is equal to 0 , and 0 otherwise. Once again, the baseline specification is augmented to include respectively $H C R_{i, t}$ and $L C R_{i, t}$, and then the same variables interacted in turn with $I S_{i, t}$ and with $I S_{i, t}$ jointly with both CRISIS ${ }_{t}$ and NOCRISIS $_{t}$ as below:

$$
\begin{aligned}
& L L P_{i, t}=\beta_{0}+\beta_{1} L L P_{i, t-1}+\beta_{2} N P L_{i, t}+\beta_{3} \Delta N P L_{i, t}+\beta_{4} L O A N_{i, t}+\beta_{5} \Delta G D P_{t}+\beta_{6} \text { CRISIS }_{t}+ \\
& +\beta_{7} \Delta G D P_{t} \cdot \text { CRISIS }_{t}+\beta_{8} C_{i, t}^{H, L} \cdot I_{i, t}+\beta_{9} C A P_{i, t}+\delta_{t}+\varepsilon_{i, t} \\
& L L P_{i, t}=\beta_{0}+\beta_{1} L L P_{i, t-1}+\beta_{2} N P L_{i, t}+\beta_{3} \Delta N P L_{i, t}+\beta_{4} L O A N_{i, t}+\beta_{5} \Delta G D P_{t}+\beta_{6} \text { CRISIS }_{t}+ \\
& +\beta_{7} \Delta G D P_{t} \cdot \text { CRISIS }_{t}+\beta_{8} \text { CR }_{i, t}^{H, L} \cdot \text { IS }_{i, t} \cdot \text { CRISIS }_{t}+\beta_{9} \text { CAP }_{i, t}+\delta_{t}+\varepsilon_{i, t} \\
& L L P_{i, t}=\beta_{0}+\beta_{1} L L P_{i, t-1}+\beta_{2} N P L_{i, t}+\beta_{3} \Delta N P L_{i, t}+\beta_{4} L O A N_{i, t}+\beta_{5} \Delta G D P_{t}+\beta_{6} \text { CRISIS }_{t}+ \\
& +\beta_{7} \Delta \text { GDP }_{t} \cdot \text { CRISIS }_{t}+\beta_{8} \text { CR }_{i, t}^{H, L} \cdot \text { IS }_{i, t} \cdot \text { NOCRISIS }_{t}+\beta_{9} \text { CAP }_{i, t}+\delta_{t}+\varepsilon_{i, t}
\end{aligned}
$$

where $C R_{i, t}^{H, L}$ is alternatively $H C R_{i, t}$ or $L C R_{i, t}$.

The results in Table 10 (for $H C R_{i, t}$ ) and in Table 11 (for $L C R_{i, t}$ ) confirm that the countercyclical behaviour of LLP is more pronounced for banks with a lower coverage ratio.

CR is also a measure of risk. Following Lepetit et al. (2014), we use as a proxy for bank risk the standard deviation of adjusted Return on Equity, computed using 3-year rolling windows $\left(R I S K_{i, t}\right)$. HRISK $K_{i, t}$ is a dummy variable which takes value 1 if $R I S K_{i, t}$ for the $i$-th bank is greater than that for the $75^{\text {th }}$ percentile of the sample distribution and 0 otherwise. $L R I S K_{i, t}$ is instead a dummy equal to 1 when $\operatorname{HRISK}_{i, t}$ is equal to 0, and 0 otherwise. Equations (8.1), (8.2) and (8.3) include respectively the dummies $H_{R I S K}$, and $L R I S K_{i, t}$, and then the same variables interacted in turn with $I S_{i, t}$ and with $I S_{i, t}$ jointly with both CRISIS $_{t}$ and NOCRISIS ${ }_{t}$

$$
\begin{aligned}
& L L P_{i, t}=\beta_{0}+\beta_{1} L L P_{i, t-1}+\beta_{2} N P L_{i, t}+\beta_{3} \Delta N P L_{i, t}+\beta_{4} L O A N_{i, t}+\beta_{5} \Delta G D P_{t}+\beta_{6} \text { CRISIS }_{t}+ \\
& +\beta_{7} \Delta \text { GDP }_{t} \cdot \text { CRISIS }_{t}+\beta_{8} \text { RISK }_{I} S_{i, t}+\beta_{9} \text { CAP }_{i, t}+\delta_{t}+\varepsilon_{i, t} \\
& L L P_{i, t}=\beta_{0}+\beta_{1} L L P_{i, t-1}+\beta_{2} N P L_{i, t}+\beta_{3} \Delta N P L_{i, t}+\beta_{4} L O A N_{i, t}+\beta_{5} \Delta G D P_{t}+\beta_{6} \text { CRISIS }_{t}+ \\
& +\beta_{7} \Delta G D P_{t} \cdot \text { CRISIS }_{t}+\beta_{8} \operatorname{RISK}_{i, t}^{H, L} \cdot I_{i, t} \cdot \text { CRISIS }_{t}+\beta_{9} \operatorname{CAP}_{i, t}+\delta_{t}+\varepsilon_{i, t} \\
& L L P_{i, t}=\beta_{0}+\beta_{1} L L P_{i, t-1}+\beta_{2} N P L_{i, t}+\beta_{3} \Delta N P L_{i, t}+\beta_{4} L O A N_{i, t}+\beta_{5} \Delta G D P_{t}+\beta_{6} \text { CRISIS }_{t}+ \\
& +\beta_{7} \Delta G D P_{t} \cdot \text { CRISIS }_{t}+\beta_{8} \text { RISK }_{i, t}^{H, L} \cdot \text { IS }_{i, t} \cdot \text { NOCRISIS }_{t}+\beta_{9} \text { CAP }_{i, t}+\delta_{t}+\varepsilon_{i, t}
\end{aligned}
$$

where $R I S K_{i, t}^{H, L}$ is alternatively $H_{R I S K}$ or $L R I S K_{i, t}$.

Table 12 (for HRISK $K_{i, t}$ ) and Table 13 (for LRISK $_{i, t}$ ) show that the coefficient on HRISKi,t • $I S_{i, t} \cdot$ CRISIS $_{t}$ in Equation (8.2) is again statistical significant and greater than the one estimated for $I S_{i, t} \bullet$ CRISIS $_{t}$ in Equation (2). 


\subsection{Local Banking}

Finally, we focus on the CCBs, which are typically small local banks (LBs). As pointed out by Di Salvo and Ferri (1994), Ferri and Mattesini (1997) and Cosci and Mattesini (1998), Italian CCBs have three main features: 1) they are typically local banks, closely linked to the local economy, 2) they are generally relatively small banks, 3) being cooperative banks the incentives for their managers significantly differ from those of other banks. To investigate whether local banks behave differently, we augment the baseline regressions (1-4) as follows:

$$
\begin{aligned}
& L L P_{i, t}=\beta_{0}+\beta_{1} L L P_{i, t-1}+\beta_{2} N P L_{i, t}+\beta_{3} \Delta N P L_{i, t}+\beta_{4} L O A N_{i, t}+\beta_{5} \Delta G D P_{t}+\beta_{6} \text { CRISIS }_{t}+ \\
& +\beta_{7} \Delta \text { GDP }_{t} \cdot \text { CRISIS }_{t}+\beta_{8} I_{i, t} \cdot L O C A L_{i, t}+\beta_{9} \text { CAP }_{i, t}+\delta_{t}+\varepsilon_{i, t} \\
& L L P_{i, t}=\beta_{0}+\beta_{1} L L P_{i, t-1}+\beta_{2} N P L_{i, t}+\beta_{3} \Delta N P L_{i, t}+\beta_{4} L O A N_{i, t}+\beta_{5} \Delta G D P_{t}+\beta_{6} \text { CRISIS }_{t}+ \\
& +\beta_{7} \Delta G D P_{t} \cdot \text { CRISIS }_{t}+\beta_{8} I_{i, t} \cdot \operatorname{LOCAL}_{i, t}+\beta_{9} \text { CAP }_{i, t}+\beta_{10} \operatorname{SIGN}_{i, t}+\delta_{t}+\varepsilon_{i, t} \\
& L L P_{i, t}=\beta_{0}+\beta_{1} L L P_{i, t-1}+\beta_{2} N P L_{i, t}+\beta_{3} \Delta N P L_{i, t}+\beta_{4} L O A N_{i, t}+\beta_{5} \Delta G D P_{t}+\beta_{6} \text { CRISIS }_{t}+ \\
& +\beta_{7} \Delta \text { GDP }_{t} \cdot \text { CRISIS }_{t}+\beta_{8} \text { IS }_{i, t} \cdot \text { LOCAL }_{i, t} \cdot \text { CRISIS }_{t}+\beta_{9} \text { CAP }_{i, t}+\delta_{t}+\varepsilon_{i, t} \\
& L L P_{i, t}=\beta_{0}+\beta_{1} L L P_{i, t-1}+\beta_{2} N P L_{i, t}+\beta_{3} \Delta N P L_{i, t}+\beta_{4} L O A N_{i, t}+\beta_{5} \Delta G D P_{t}+\beta_{6} \text { CRISIS }_{t}+ \\
& +\beta_{7} \Delta \text { GDP }_{t} \cdot \text { CRISIS }_{t}+\beta_{8} \text { IS }_{i, t} \cdot \text { LOCAL }_{i, t} \cdot \text { NOCRISIS }_{t}+\beta_{9} \text { CAP }_{i, t}+\delta_{t}+\varepsilon_{i, t}
\end{aligned}
$$

where $L O C A L_{i, t}$ is a dummy variable which takes value 1 for local banks and 0 otherwise.

The results in Table 14 point to a cyclical behaviour in LLP for local banks as well. However, this feature is weaker than for banks in general over the full sample, but stronger during the crisis. To shed further light on this issue, we estimate three further specifications including respectively interactive dummies for the effect of collateralised credit, overage ratios and of the level risk on LLPs, as follows:

$$
\begin{aligned}
& L L P_{i, t}=\beta_{0}+\beta_{1} L L P_{i, t-1}+\beta_{2} N P L_{i, t}+\beta_{3} \Delta N P L_{i, t}+\beta_{4} L O A N_{i, t}+\beta_{5} \Delta G D P_{t}+\beta_{6} \text { CRISIS }_{t}+ \\
& +\beta_{7} \Delta G D P_{t} \cdot \text { CRISIS }_{t}+\beta_{8} G U A_{i, t}^{H, L} \cdot I_{i, t} \cdot L O C A L_{i, t}+\beta_{9} C A P_{i, t}+\delta_{t}+\varepsilon_{i, t} \\
& L L P_{i, t}=\beta_{0}+\beta_{1} L L P_{i, t-1}+\beta_{2} N P L_{i, t}+\beta_{3} \Delta N P L_{i, t}+\beta_{4} L O A N_{i, t}+\beta_{5} \Delta G D P_{t}+\beta_{6} \text { CRISIS }_{t}+ \\
& +\beta_{7} \Delta G D P_{t} \cdot \text { CRISIS }_{t}+\beta_{8} G U A_{i, t}^{H, L} \cdot I_{i, t} \cdot \operatorname{LOCAL}_{i, t} \cdot \text { CRISIS }_{t}+\beta_{9} \text { CAP }_{i, t}+\delta_{t}+\varepsilon_{i, t} \\
& L L P_{i, t}=\beta_{0}+\beta_{1} L L P_{i, t-1}+\beta_{2} N P L_{i, t}+\beta_{3} \Delta N P L_{i, t}+\beta_{4} L O A N_{i, t}+\beta_{5} \Delta G D P_{t}+\beta_{6} \text { CRISIS }_{t}+ \\
& +\beta_{7} \Delta \text { GDP }_{t} \cdot \text { CRISIS }_{t}+\beta_{8} G U A_{i, t}^{H, L} \cdot I_{i, t} \cdot \text { LOCAL }_{i, t} \cdot \text { NOCRISIS }_{t}+\beta_{9} \text { CAP }_{i, t}+\delta_{t}+\varepsilon_{i, t}
\end{aligned}
$$

where $G U A_{i, t}^{H, L}$, as before, is alternatively $H G U A_{i, t}$ or $L G U A_{i, t}$,

$$
\begin{aligned}
L L P_{i, t}= & \beta_{0}+\beta_{1} L L P_{i, t-1}+\beta_{2} N P L_{i, t}+\beta_{3} \Delta N P L_{i, t}+\beta_{4} L O A N_{i, t}+\beta_{5} \Delta G D P_{t}+\beta_{6} C \text { ISIS }_{t}+ \\
& +\beta_{7} \Delta G D P_{t} \cdot \text { CRISIS }_{t}+\beta_{8} C R_{i, t}^{H, L} \cdot I S_{i, t} \cdot L O C A L_{i, t}+\beta_{9} C \operatorname{CAP}_{i, t}+\delta_{t}+\varepsilon_{i, t}
\end{aligned}
$$




$$
\begin{aligned}
& L L P_{i, t}=\beta_{0}+\beta_{1} L L P_{i, t-1}+\beta_{2} N P L_{i, t}+\beta_{3} \Delta N P L_{i, t}+\beta_{4} L O A N_{i, t}+\beta_{5} \Delta G D P_{t}+\beta_{6} C \text { RISIS }_{t}+ \\
& +\beta_{7} \Delta G D P_{t} \cdot \text { CRISIS }_{t}+\beta_{8} \text { CR }_{i, t}^{H, L} \cdot \text { IS }_{i, t} \cdot \text { CRISIS }_{t} \cdot \text { LOCAL }_{i, t}+\beta_{9} \text { CAP }_{i, t}+\delta_{t}+\varepsilon_{i, t} \\
& L L P_{i, t}=\beta_{0}+\beta_{1} L L P_{i, t-1}+\beta_{2} N P L_{i, t}+\beta_{3} \Delta N P L_{i, t}+\beta_{4} L O A N_{i, t}+\beta_{5} \Delta G D P_{t}+\beta_{6} \text { CRISIS }_{t}+ \\
& +\beta_{7} \Delta \text { GDP }_{t} \cdot \text { CRISIS }_{t}+\beta_{8} \text { CR }_{i, t}^{H, L} \cdot \text { IS }_{i, t} \cdot \text { NOCRISIS }_{t} \cdot \text { LOCAL }_{i, t}+\beta_{9} \text { CAP }_{i, t}+\delta_{t}+\varepsilon_{i, t}
\end{aligned}
$$

where $C R_{i, t}^{H, L}$ again is alternatively $H C R_{i, t}$ or $L C R_{i, t}$, and

$$
\begin{aligned}
& L L P_{i, t}=\beta_{0}+\beta_{1} L L P_{i, t-1}+\beta_{2} N P L_{i, t}+\beta_{3} \Delta N P L_{i, t}+\beta_{4} L O A N_{i, t}+\beta_{5} \Delta G D P_{t}+\beta_{6} \text { CRISIS }_{t}+ \\
& +\beta_{7} \text { CRISIS }_{t}+\beta_{8} \Delta G D P_{t} \cdot \text { CRISIS }_{t}+\beta_{9} \text { RISK } \text { IS }_{i, t}+\beta_{10} \text { CAP }_{i, t}+\delta_{t}+\varepsilon_{i, t} \\
& L L P_{i, t}=\beta_{0}+\beta_{1} L L P_{i, t-1}+\beta_{2} N P L_{i, t}+\beta_{3} \Delta N P L_{i, t}+\beta_{4} L O A N_{i, t}+\beta_{5} \Delta G D P_{t}+\beta_{6} C \text { RISIS }_{t}+ \\
& +\beta_{7} \text { CRISIS }_{t}+\beta_{8} \Delta G D P_{t} \cdot \text { CRISIS }_{t}+\beta_{9} \text { RISK }_{i, t}^{H, L} \cdot \text { IS }_{i, t} \cdot \text { CRISIS }_{t}+\beta_{10} \text { CAP }_{i, t}+\delta_{t}+\varepsilon_{i, t} \\
& L L P_{i, t}=\beta_{0}+\beta_{1} L L P_{i, t-1}+\beta_{2} N P L_{i, t}+\beta_{3} \Delta N P L_{i, t}+\beta_{4} L O A N_{i, t}+\beta_{5} \Delta G D P_{t}+\beta_{6} \text { CRISIS }_{t}+ \\
& +\beta_{7} \text { CRISIS }_{t}+\beta_{8} \Delta G D P_{t} \cdot \text { CRISIS }_{t}+\beta_{9} \text { RISK }_{i, t}^{H, L} \cdot \text { IS }_{i, t} \cdot \text { NOCRISIS }_{t}+\beta_{10} \text { CAP }_{i, t}+\delta_{t}+\varepsilon_{i, t}
\end{aligned}
$$

where ISSK $_{i, t}^{H, L}$ is alternatively HRISK $_{i, t}$ or LRISK $_{i, t}$.

The results are reported in Tables $14-20$. They indicate that the stronger cyclicality of LLP in local banks can be explained by: 1) a bigger collateral (Table 15); 2) a lower coverage ratio (Tables 17 and 18) and 3) higher risk (Tables 19 and 20). (2) is consistent with the fact that supervisory activity is stronger and more focused on LLPs for local banks (capital requirements instead for big banks), and also the lower coverage ratio of LBs before (and during) the crisis. As already mentioned, CR is also a measure of risk (as confirmed by 3).

\section{Conclusions}

This paper examines the determinants of LLP in Italian banks over the period 2001-2012, using balance sheet data. In addition to the most common explanatory variables, we also consider the effects of guaranteed loans, coverage ratios and the level of risk. Moreover, we also provide evidence for local banks.

The analysis is carried out using the generalized method of moments (GMM) with first differences (see Arellano and Bond, 1991). The findings suggest that the main drivers of LLP in Italian banks are non-discretionary behaviour and cyclical components, whilst the discretionaty behaviour of bank managers and expectations about future potential losses do not appear to play a role. Further, a higher level of collateralised loans, which can reduce credit risk and future losses, has a negative and significant impact. 
Concerning local banks, their LLP strategy seems to be less pro-cyclical than that of banks in general. However, during the economic crisis of 2008-2012, it was more cyclical than for the full sample of banks. Possible reasons are the fact that the loans of local banks are generally more collateralised, their cyclical behavior is more strongly affected by supervisory activity, and their coverage ratio is lower than for banks in general. 


\section{References}

[1] AHMED, A.S. - TAKEDA, C. - THOMAS, S. (1999). "Bank loan loss provisions: a reexamination of capital management, earnings management and signaling effects”, Journal of Accounting and Economics 28, pp. 1-25.

[2] ALTUNBAS, Y. - FAZYLOV O. - MOLYNEUX P. (2002), "Evidence on the bank lending channel in Europe”, Journal of Banking and Finance, vol. 26, pp. 2093-2110.

[3] ARELLANO M - BOND S.R. (1991), "Some tests of Specification for Panel Data: Monte Carlo Evidence on Employment equations”, Review of Economic Studies, vol. 58, pp 277 - 297

[4] ASEA, P.K. - BLOMBERG, B. (1998), “Lending cycles”, Journal of Econometrics, vol. 83, pp. 89-128.

[5] BEAVER W.H. - ENGEL E. (1996), "Discretionary behavior with respect to allowances for loan losses and the behavior of security prices”, Journal of Accounting and Economics, vol. 22, pp. 177-206.

[6] BEATTY, A. - CHAMBERLAIN, S. - MAGLIOLO, J. (1995). "Managing financial reports of commercial banks: The influence of taxes, regulatory capital, and earnings”, Journal of Accounting Research 33, n. 2 pp. 231-262.

[7] BERGER A. N. - G. F. UDELL (2002), "Small business credit availability and relationship lending: the importance of bank organisational structure”, The Economic Journal, vol. 112, F32-F53.

[8] BERNANKE B.S. - LOWN C.S. (1991), "The credit crunch”, Brooking Papers on Economic Activity, vol. 2, pp. 205-248.

[9] BIKKER J. A. (2004), “Cyclical patterns in pro.ts, provisioning and lending of banks. In Competition and efficiency” in "European banking market”, pp. 241-273, Edward Elgar.

[10] BIKKER J. A. - P. A. METZEMAKERS (2005), "Bank provisioning behaviour and prociclicality”, Research Series Supervision, n. 50, pp. 1-21.

[11] BOUVATIER V. - LEPETIT L. (2008), “Banks Procyclical behavior: does provisioning matter?” Journal of International Financial Markets, Institutions and Money, vol.18, pp 513 - 26

[12] BOUVATIER V. - LEPETIT L. - STROBEL F. (2014), "Bank income smoothing, ownership concentration and regulatory environment”, Journal of Banking and Finance, vol. 41, pp 253 - 270

[13] BRINKMANN E.J. - HORVITZ P.M. (1995), "Risk-based capital standards and the credit crunch”, Journal of Money, Credit and Banking, vol. 27(3), pp. 848-863.

[14] CAPORALE G. M. - S. DI COLLI - J. S. LOPEZ (2014) "Bank Lending Procyclicality And Credit Quality During Financial Crises”, Economic Modelling, vol. 43, pp. 142-157.

[15] COSCI S. - MATTESINI F. (1997), “Credito e sviluppo nelle province italiane”, in “Credito e sviluppo”, ed. il Mulino, pp. 89-130

[16] CHAMI R. - COSIMANO T. F. (2001), “Monetary policy with a touch of Basel”, IMF Working Paper, $01 / 151$

[17] COLLINS, J. - SHACKELFORD, D. - WAHLEN, J. (1995), "Bank differences in the coordination of regulatory capital, earnings and taxes”, Journal of Accounting Research, vol. 33, pp. 263-292.

[18] CRAIG, R. S. - DAVIS, E. P. - PASCUAL, A. G. (2006), "Sources of procyclicality in east Asian financial systems”, in S Gerlach and P Gruenwald (eds), Procyclicality of Financial Systems in Asia, PP 55-123.

[19] DAVIS, E. P. - ZHU, H. (2009) “Commercial property prices and bank performance”, Quarterly Review of Economics and Finance, vol. 49, pp. 1341-59.

[20] DI COLLI S. - A. GIRARDI (2011), "Restrizione creditizia durante la crisi del 2007 -2009 e il ruolo anticiclico delle Banche di Credito Cooperativo”, mimeo.

[21] DI GIULIO D. (2009), "Finanziamenti bancari al settore produttivo: credit crunch o extra-credito", Temi di Economia e Finanza, ABI, Novembre, n.1

[22] DI SALVO - R. FERRI G. (1994), "Credito Cooperativo, finanziamento alle piccole e medie imprese e sviluppo decentrato: valutazioni teoriche e primi riscontri empirici”, Cooperazione di Credito, ottobredicembre, pp. 309-369

[23] EHRMANN M. - GAMBACORTA L. - MARTINEZ-PAGÈS J. - SEVESTRE P. -WORMS A. (2003), "Financial system and the role of banks in monetary policy transmission in the Euro Area", in: Monetary policy transmission in the Euro area. Angeloni I., Kashyap A., Mojon. B. (Eds), Cambridge University Press.

[24] FERRI G. - MATTESINI F. (1997), "Finance, Human Capital and Infrastructure: an empirical investigation on postwar Italian growth”, Temi di discussione della Banca d'Italia, n. 321. 
[25] FONSECA A. R. - GONZALEZ F. (2008), “Cross-conuntry determinants of bank income smoothing by managing loan-loss provisions”, Journal of Banking and Finance, vol. 32, pp. 217-228.

[26] FUDENBERG, D. - TIROLE, J. (1995), “A theory of income and dividend smoothing based on incumbency rents”, Journal of Political Economy 103(1), pp. 75-93

[27] FURFINE C. (2001), "Bank portfolio allocation: the impact of capital requirements, regulatory monitoring and economic conditions”, Journal of Financial Services Research, vol. 20, pp. 33-56.

[28] GAMBACORTA L. - MISTRULLI P. E. (2004), “Does bank capital affect lending behavior?”, Journal of Financial Intermediation, 13, 436-457.

[29] GAMBACORTA L. (2005), “Inside the bank lending channel”, European Economic Review, 49, $1737-1759$.

[30] GREENWALT M. J. - SINKEY J.R. (1988), "Bank loan loss provisions and the income smoothing hypothesis: An empirical analysis”, Journal of Financial Services Research, vol. 1, pp. 301-318.

[31] HANCOCK, D. - WILCOX J.A. (1998), "The credit crunch and the availability of credit to small businesses", Journal of Banking and Finance, vol. 22, pp. 983-1014.

[32] KANAGARETNAM K. - LOBO G.J. - YANG D.H. (2005), "Determinants of signaling by banks through loan loss provisions”, Journal of Business Research, vol. 58, pp. 312- 320.

[33] KASHYAP A.K. - STEIN, J.C. (2000), "What do a million observations on bank say about the transmission of monetary policy”, The American Economic Review, vol. 90, pp. 407- 428.

[34] KEETON W. R. (1999), “Does faster loan growth lead to higher loan losses?”, Federal Reserve Bank of Kansas City Economic Review, 84, pp. 57-75.

[35] KISHAN, R.P. - OPIELA, T.P. (2000), “Bank size, bank capital, and the bank lending channel”, Journal of Money, Credit and Banking, vol. 32(1), pp. 121-141.

[36] LIU, C. - RYAN, S. - WAHLEN, J. (1997), “Differential valuation implications of loan loss provisions across banks and fiscal agents”, The Accounting Review vol. 72(1) pp. 133-146.

[37] LOWN, C. - MORGAN D. P. (2006), "The credit cycle and the business cycle: new findings using the loan officer opinion survey”, Journal of Money, Credit, and Banking.

[38] MOYER, S.E. (1990), “Capital adequacy ratio regulations and accounting choices in commercial banks”, Journal of Accounting and Economics, 13 (July): pp. 123-154.

[39] PACKER F. - ZHU H. (2012) “Loan Loss provisioning practices of Asian Banks “ BIS Working Papers, No 375

[40] PEEK J. - ROSENGREN, E.S. (1995), “Bank regulation and credit crunch”, Journal of Banking and Finance, vol. 19, pp. 679-692.

[41] PEEK, J. - ROSENGREN E. S. - TOOTELL G.M. (2003), "Identifying the macroeconomic effect of loan supply shocks”, Journal of Money, Credit, and Banking, vol. 35(6), pp. 931-946.

[42] SOEDARMONO, W. - TARAZI A. - AGUSMAN A. - MONROE G. S. - GASBARRO D. (2012). "Loan loss provisions and lending behaviour of banks: Asian evidence during 1992-2009”, working paper (http://papers.ssrn.com/sol3/papers.cfm?abstract_id=2049217).

[43] WAHLEN, J. (1994). "The nature of information in commercial bank loan loss disclosures”, The Accounting Review, vol. 69(3) pp. 455-478.

[44] ZICCHINO L. (2005), “A model of bank capital, lending and the macroeconomy: Basel I versus Basel II”, Bank of England Working Paper No. 270. 


\section{List of Figures and Tables}

Figure 1. Loan Loss Provisions and real GDP growth

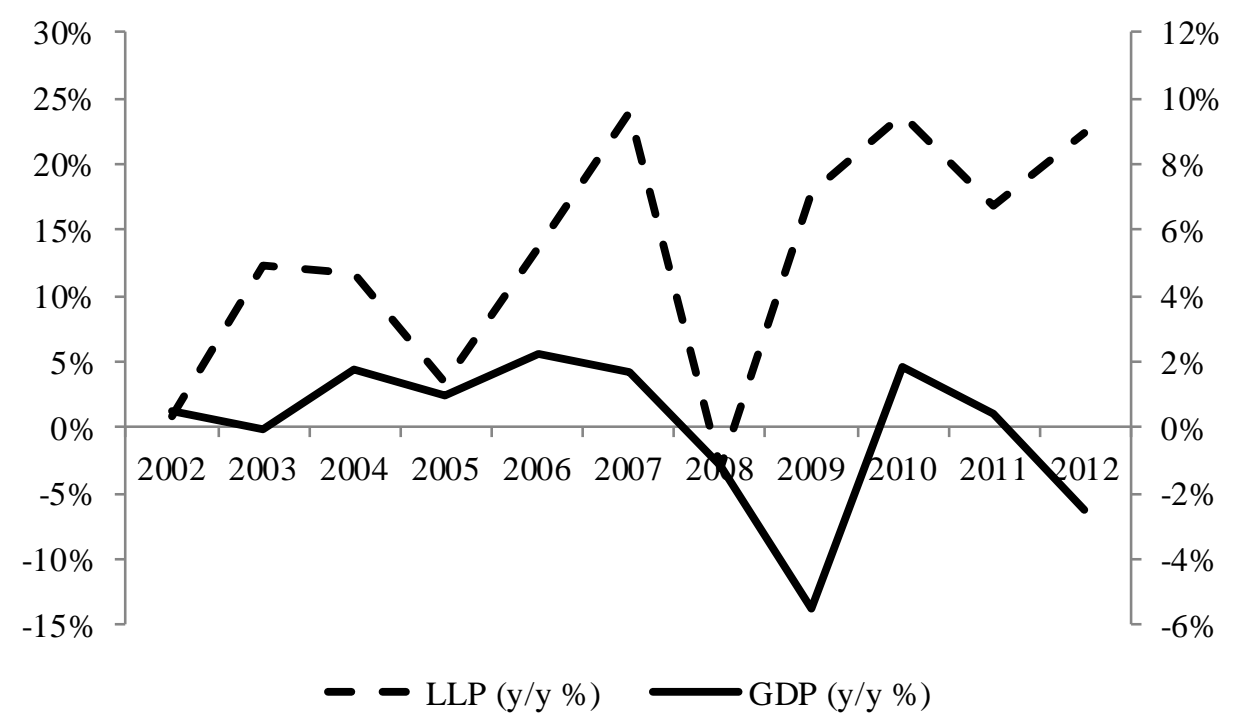

Note. Annual growth of Loan Loss Provisions (left scale) and Italian real GDP (right scale) from 2001 to 2012.

Source: Authors' calculations using data from Istat and ABI (Italian Banking Association). 
Figure 2a. Loan Loss Provisions over Total Loans

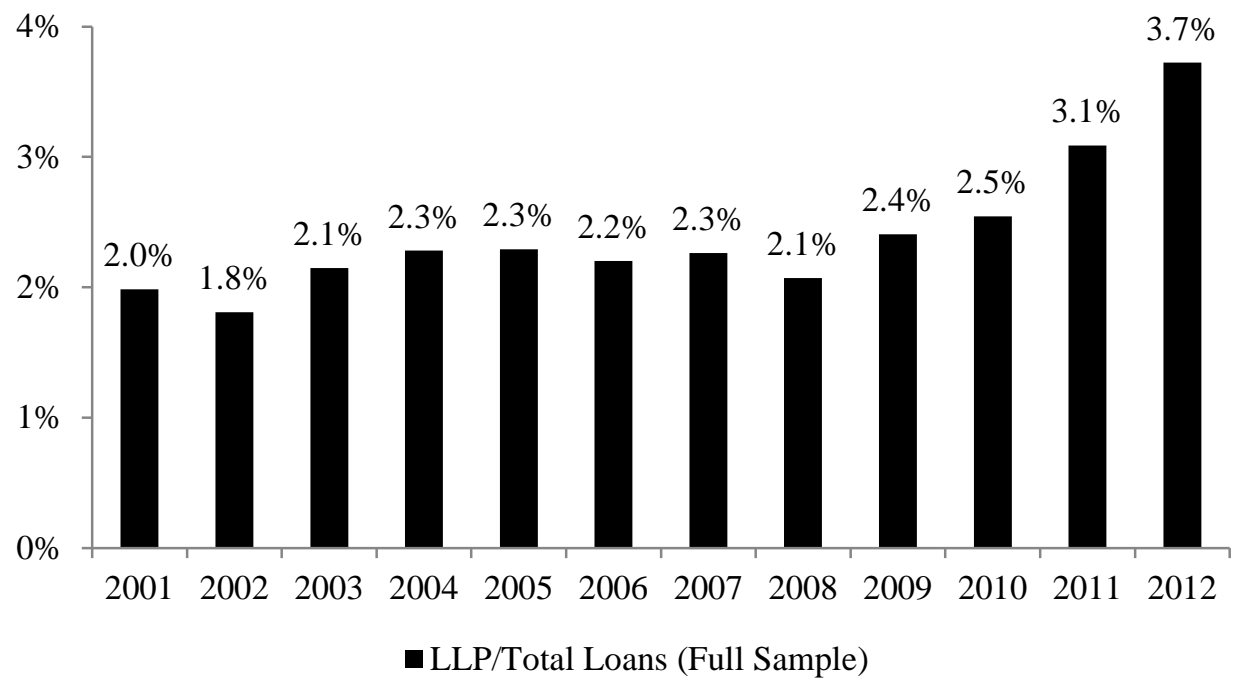

Note Loan Loss Provisions for Bad Loans over Total Loans from 2001 to 2012.

Source: Authors' calculations using data from ABI (Italian Banking Association).

Figure 2b. Coverage Ratios

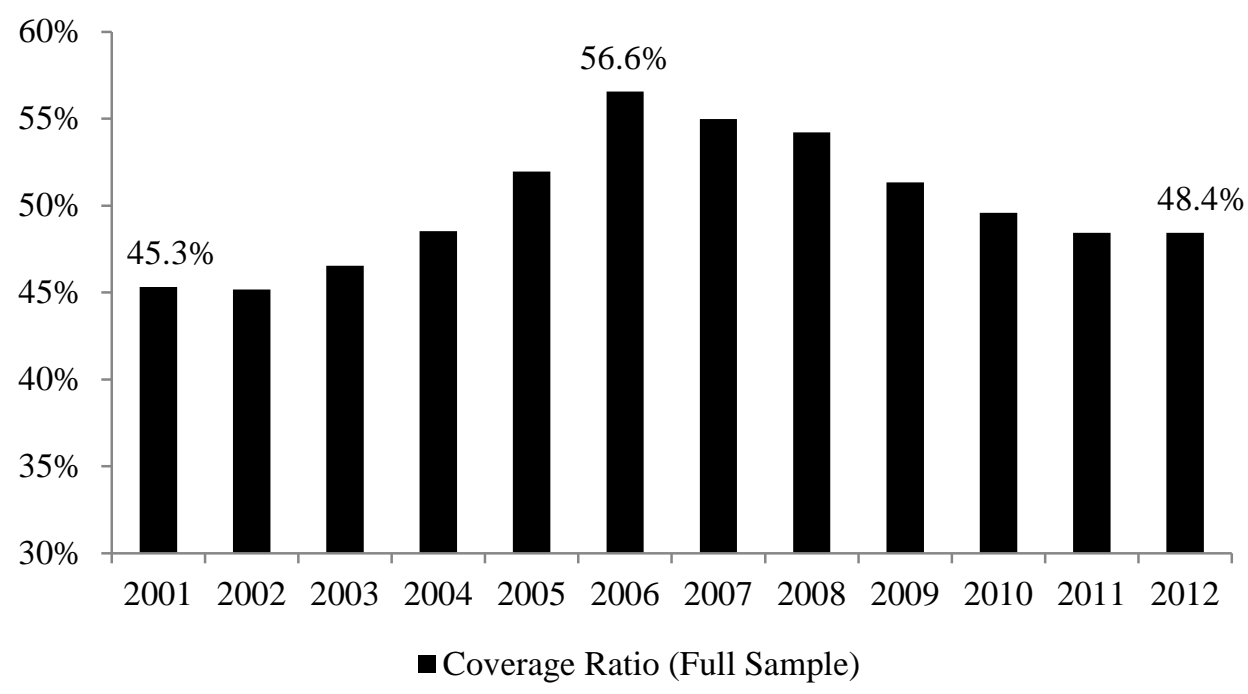

Note Coverage Ratios for the Italian banking sector from 2001 to 2012.

Source: Authors' calculations using data from ABI (Italian Banking Association). 
Figure 3a: Loan Loss Provisions over Total Loans. Full sample vs Local Banks

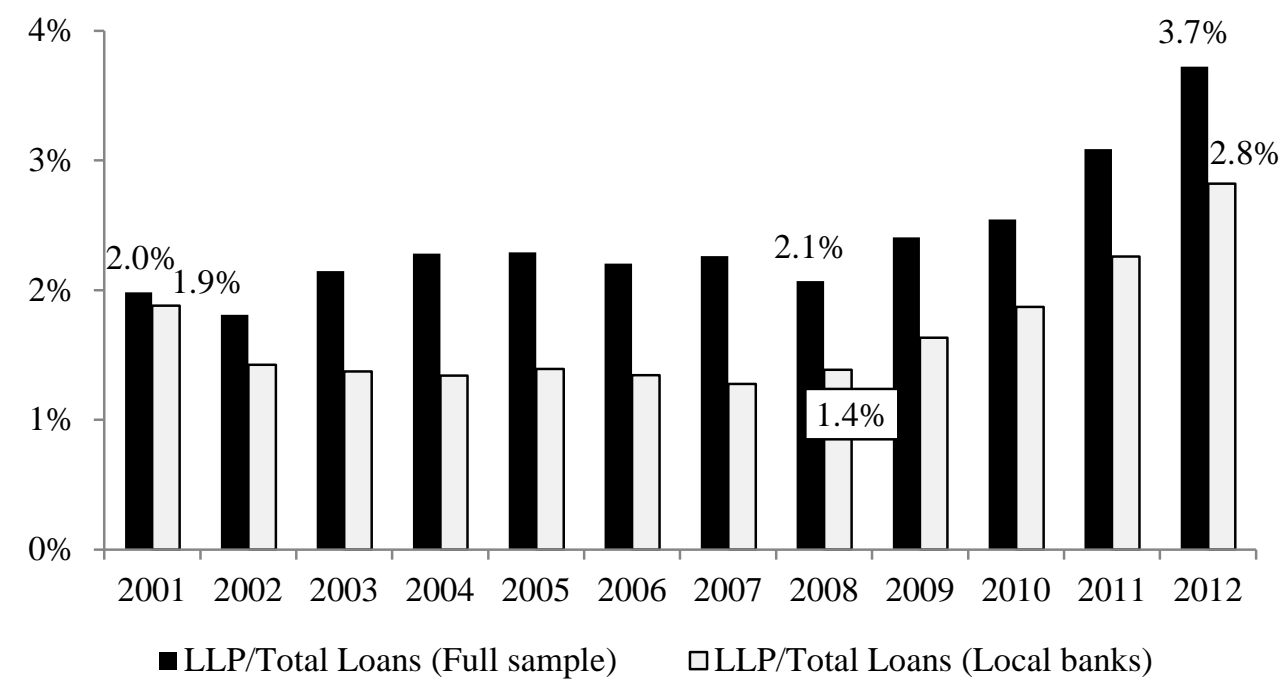

Note Loan Loss Provisions on Bad Loans over Total Loans from 2001 to 2012 for the Italian banking sector and Local Banks.

Source: Authors’ calculations using data from ABI (Italian Banking Association).

Figure 3b: Coverage Ratios. Full sample vs Local Banks

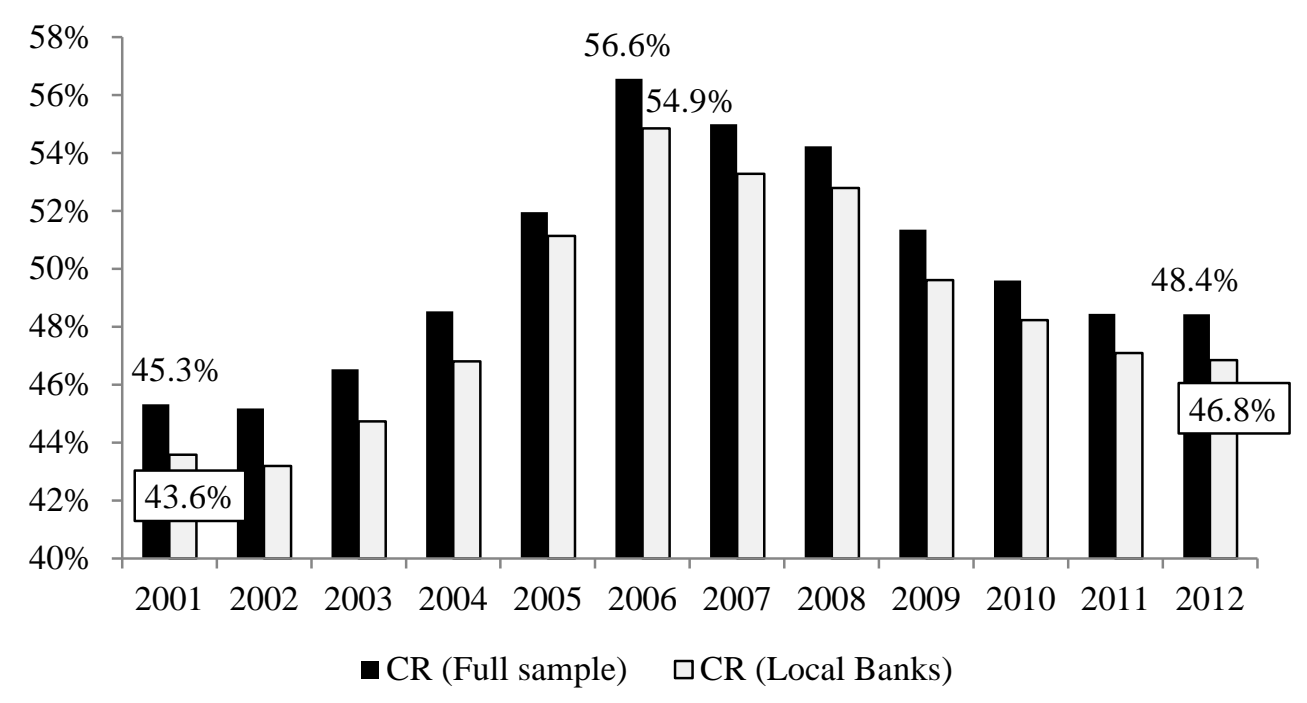

Note Coverage Ratios for the Italian banking sector and Local Banks from 2001 to 2012.

Source: Authors' calculations on data by ABI (Italian Banking Association). 
Table 1. List of variables

\begin{tabular}{|c|c|c|c|}
\hline Variable & Definition & $\begin{array}{c}\# \\
\text { Observations } \\
\end{array}$ & Source \\
\hline$L L P_{i, t}$ & Loan Loss Provisions on Bad Loans over Total Assets ratio & 5,861 & $\mathrm{ABI}$ \\
\hline$N P L_{i, t}$ & Bad Loans over Total Loans ratio & 5,861 & $\mathrm{ABI}$ \\
\hline$\triangle N P L_{i, t}$ & One period ahead first - difference of $N P L_{i, t}$ & 5,348 & $\mathrm{ABI}$ \\
\hline$L O A N_{i, t}$ & Total Loans over Total Assets ratio & 5,861 & $\mathrm{ABI}$ \\
\hline$\Delta G D P_{t}$ & Annual real GDP rate of growth & 5,861 & Istat \\
\hline$I S_{i, t}$ & $\begin{array}{l}\text { Income Smoothing: Earnings before interest, taxes and loan loss provision over total } \\
\text { assets ratio }\end{array}$ & 5,861 & $\mathrm{ABI}$ \\
\hline$C A P_{i, t}$ & $\begin{array}{l}\text { Dummy variable which takes value } 1 \text { if the bank i-th has a Tier1 Ratio greater than } \\
\text { the level associated to the } 75 \text { th percentile of the sample distribution ( } 0 \text { otherwise) }\end{array}$ & 5,861 & $\mathrm{ABI}$ \\
\hline$S I G N_{i, t}$ & One - year ahead percentage change of $I S_{i, t}$ & 5,348 & $\mathrm{ABI}$ \\
\hline
\end{tabular}

Table 2. Number of observations by year

\begin{tabular}{ccc}
\hline \hline & Full Sample & Local Banks \\
\hline \hline & & 377 \\
2001 & 483 & 385 \\
2003 & 494 & 385 \\
2004 & 495 & 388 \\
2005 & 503 & 389 \\
2006 & 505 & 391 \\
2007 & 509 & 390 \\
2008 & 509 & 384 \\
2009 & 502 & 374 \\
2010 & 490 & 367 \\
2011 & 474 & 366 \\
2012 & 468 & 330 \\
\hline Total Obs. & 429 & \\
\hline \hline
\end{tabular}

Source: Italian Banking Association Balance sheets and Financial Statement database. 
Table 3. Summary statistics for the main variables

\begin{tabular}{|c|c|c|c|c|c|c|c|}
\hline & $L L P_{i, t}$ & $N P L_{i, t}$ & $\Delta N P L_{i, t}$ & $L O A N_{i, t}$ & $I S_{i, t}$ & $C A P_{i, t}$ & $S I G N_{i, t}$ \\
\hline \multicolumn{8}{|c|}{ All banks (5861 observations) } \\
\hline Mean & 0.0133 & 0.0438 & 0.0010 & 0.6485 & 0.0079 & 0.2801 & -0.1438 \\
\hline Maximum & 0.1996 & 0.6491 & 0.2941 & 0.9769 & 0.0667 & 1.0000 & 130.1400 \\
\hline Minimum & 0.0000 & 0.0000 & -0.5746 & 0.0095 & -0.0702 & 0.0000 & -257.8800 \\
\hline Std. Dev. & 0.0144 & 0.0476 & 0.0233 & 0.1450 & 0.0076 & 0.4491 & 5.5783 \\
\hline \multicolumn{8}{|c|}{ Cluster 1 Big size (1465 observations) } \\
\hline Mean & 0.0149 & 0.0406 & 0.0032 & 0.6950 & 0.0079 & 0.1987 & -0.2530 \\
\hline Maximum & 0.1328 & 0.2815 & 0.2070 & 0.9348 & 0.0646 & 1.0000 & 71.1310 \\
\hline Minimum & 0.0000 & 0.0000 & -0.2562 & 0.0095 & -0.0573 & 0.0000 & -205.2200 \\
\hline Std. Dev. & 0.0132 & 0.0329 & 0.0193 & 0.1415 & 0.0079 & 0.3991 & 6.5859 \\
\hline \multicolumn{8}{|c|}{ Cluster 2 Low size (4396 observations) } \\
\hline Mean & 0.0128 & 0.0449 & 0.0004 & 0.6329 & 0.0079 & 0.3118 & -0.1088 \\
\hline Maximum & 0.1996 & 0.6491 & 0.2941 & 0.9769 & 0.0667 & 1.0000 & 130.1400 \\
\hline Minimum & 0.0000 & 0.0000 & -0.5746 & 0.0132 & -0.0702 & 0.0000 & -257.8800 \\
\hline Std. Dev. & 0.0147 & 0.0515 & 0.0245 & 0.1429 & 0.0075 & 0.4633 & 5.2146 \\
\hline \multicolumn{8}{|c|}{ Cluster 3 High Guarantees (1465 observations) } \\
\hline Mean & 0.0176 & 0.0606 & 0.0011 & 0.6028 & 0.0075 & 0.4611 & -0.2697 \\
\hline Махітum & 0.1400 & 0.4371 & 0.1383 & 0.9313 & 0.0470 & 1.0000 & 130.1400 \\
\hline Minimum & 0.0000 & 0.0000 & -0.2340 & 0.0208 & -0.0675 & 0.0000 & -257.8800 \\
\hline Std. Dev. & 0.0176 & 0.0597 & 0.0224 & 0.1464 & 0.0075 & 0.4986 & 8.7545 \\
\hline \multicolumn{8}{|c|}{ Cluster 4 Low Guarantees (4396 observations) } \\
\hline Mean & 0.0119 & 0.0383 & 0.0010 & 0.6637 & 0.0081 & 0.2097 & -0.1047 \\
\hline Maximum & 0.1996 & 0.6491 & 0.2941 & 0.9769 & 0.0667 & 1.0000 & 71.1310 \\
\hline Minimum & 0.0000 & 0.0000 & -0.5746 & 0.0095 & -0.0702 & 0.0000 & -205.2200 \\
\hline Std. Dev. & 0.0128 & 0.0413 & 0.0237 & 0.1413 & 0.0076 & 0.4071 & 4.1236 \\
\hline \multicolumn{8}{|c|}{ Cluster 5 High Risk (1479 observations) } \\
\hline Mean & 0.0159 & 0.0477 & 0.0059 & 0.6732 & 0.0053 & 0.2508 & -0.5744 \\
\hline Maximum & 0.1400 & 0.4371 & 0.1115 & 0.9641 & 0.0667 & 1.0000 & 130.1400 \\
\hline Minimum & 0.0000 & 0.0000 & -0.2562 & 0.0095 & -0.0702 & 0.0000 & -257.8800 \\
\hline Std. Dev. & 0.0159 & 0.0456 & 0.0205 & 0.1498 & 0.0121 & 0.4336 & 9.0283 \\
\hline \multicolumn{8}{|c|}{ Cluster 6 Low Risk (4382 observations) } \\
\hline Mean & 0.0125 & 0.0425 & -0.0004 & 0.6401 & 0.0088 & 0.2913 & -0.0046 \\
\hline Maximum & 0.1996 & 0.6491 & 0.2941 & 0.9769 & 0.0461 & 1.0000 & 83.3560 \\
\hline Minimum & 0.0000 & 0.0000 & -0.5746 & 0.0681 & -0.0406 & 0.0000 & -205.2200 \\
\hline Std. Dev. & 0.0137 & 0.0482 & 0.0240 & 0.1424 & 0.0050 & 0.4544 & 3.8429 \\
\hline \multicolumn{8}{|c|}{ Cluster 7 High Coverage Ratio (3340 observations) } \\
\hline Mean & 0.0149 & 0.0493 & -0.0027 & 0.6049 & 0.0089 & 0.3577 & -0.0235 \\
\hline Махітum & 0.1996 & 0.6491 & 0.2941 & 0.9769 & 0.0493 & 1.0000 & 71.1310 \\
\hline Minimum & 0.0000 & 0.0000 & -0.5746 & 0.0095 & -0.0675 & 0.0000 & -205.2200 \\
\hline Std. Dev. & 0.0173 & 0.0571 & 0.0271 & 0.1518 & 0.0076 & 0.4794 & 4.3177 \\
\hline \multicolumn{8}{|c|}{ Cluster 8 Low Coverage Ratio (2521 observations) } \\
\hline Mean & 0.0113 & 0.0366 & 0.0068 & 0.7062 & 0.0066 & 0.1697 & -0.3263 \\
\hline Махітum & 0.0658 & 0.2163 & 0.1383 & 0.9641 & 0.0667 & 1.0000 & 130.1400 \\
\hline Minimum & 0.0000 & 0.0000 & -0.0509 & 0.1172 & -0.0702 & 0.0000 & -257.8800 \\
\hline Std. Dev. & 0.0088 & 0.0294 & 0.0143 & 0.1119 & 0.0074 & 0.3755 & 7.0717 \\
\hline \multicolumn{8}{|c|}{$\begin{array}{l}\text { Note. Mean, maximum, minimum and standard deviation are calculated over the sample period } 2001-2012 . L L P_{i, t} \text { is the ratio of Loan Loss } \\
\text { Provisions on Bad Loans to Total Assets. } N P L_{i, t} \text { is the ratio of Bad Loans to Total Loans. } \triangle N P L_{t} \text { is the one period ahead first }- \text { difference of } \\
N P L_{i, t} . L O A N_{i, t} \text { is the ratio of Total Loans to Total Assets. } I S_{i, t} \text { is the ratio of earnings before interest, taxes and loan loss provision to total assets. } \\
C A P_{i, t} \text { is a dummy variable that takes value } 1 \text { if the bank has a Tier1 Ratio greater than that for the } 75 \text { th percentile of the sample distribution and } 0 \\
\text { otherwise. } S I G N_{i, t} \text { is the one - year ahead percentage change of } I S_{i, t} \text {. } \\
\text { Source: Authors' calculations using data from ABI (Italian Banking Association). }\end{array}$} \\
\hline
\end{tabular}


Table 4. Summary statistics for the main variables - Local Banks

\begin{tabular}{|c|c|c|c|c|c|c|c|}
\hline & $L L P_{i, t}$ & $N P L_{i, t}$ & $\Delta N P L_{i, t}$ & $L O A N_{i, t}$ & $I S_{i, t}$ & $C A P_{i, t}$ & $S I G N_{i, t}$ \\
\hline \multicolumn{8}{|c|}{ Local banks (4526 observations) } \\
\hline Mean & 0.0127 & 0.0442 & 0.0007 & 0.6411 & 0.0079 & 0.3000 & -0.1390 \\
\hline Maximum & 0.1996 & 0.6491 & 0.2941 & 0.9099 & 0.0470 & 1.0000 & 130.1400 \\
\hline Minimum & 0.0000 & 0.0000 & -0.5746 & 0.0132 & -0.0702 & 0.0000 & -257.8800 \\
\hline Std. Dev. & 0.0144 & 0.0505 & 0.0239 & 0.1381 & 0.0069 & 0.4583 & 5.1422 \\
\hline \multicolumn{8}{|c|}{ Cluster 1 Big size (362 observations) } \\
\hline Mean & 0.0109 & 0.0338 & 0.0062 & 0.7367 & 0.0069 & 0.0966 & -0.4590 \\
\hline Maximum & 0.0757 & 0.2123 & 0.0805 & 0.8939 & 0.0234 & 1.0000 & 2.8512 \\
\hline Minimum & 0.0008 & 0.0039 & -0.0308 & 0.3343 & -0.0352 & 0.0000 & -26.7080 \\
\hline Std. Dev. & 0.0092 & 0.0292 & 0.0114 & 0.0897 & 0.0067 & 0.2959 & 2.2491 \\
\hline \multicolumn{8}{|c|}{ Cluster 2 Low size (4164 observations) } \\
\hline Mean & 0.0129 & 0.0451 & 0.0003 & 0.6328 & 0.0080 & 0.3177 & -0.1139 \\
\hline Maximum & 0.1996 & 0.6491 & 0.2941 & 0.9099 & 0.0470 & 1.0000 & 130.1400 \\
\hline Minimum & 0.0000 & 0.0000 & -0.5746 & 0.0132 & -0.0702 & 0.0000 & -257.8800 \\
\hline Std. Dev. & 0.0148 & 0.0519 & 0.0246 & 0.1384 & 0.0069 & 0.4656 & 5.3019 \\
\hline \multicolumn{8}{|c|}{ Cluster 3 High Guarantees (1408 observations) } \\
\hline Mean & 0.0173 & 0.0603 & 0.0009 & 0.6015 & 0.0073 & 0.3750 & -0.2616 \\
\hline Maximum & 0.1400 & 0.4102 & 0.1383 & 0.8933 & 0.0470 & 1.0000 & 130.1400 \\
\hline Minimum & 0.0000 & 0.0000 & -0.2340 & 0.0208 & -0.0675 & 0.0000 & -257.8800 \\
\hline Std. Dev. & 0.0175 & 0.0596 & 0.0227 & 0.1456 & 0.0074 & 0.4842 & 8.9119 \\
\hline \multicolumn{8}{|c|}{ Cluster 4 Low Guarantees (3118 observations) } \\
\hline Mean & 0.0106 & 0.0370 & 0.0006 & 0.6590 & 0.0082 & 0.2661 & -0.0875 \\
\hline Maximum & 0.1996 & 0.6491 & 0.2941 & 0.9099 & 0.0320 & 1.0000 & 42.1850 \\
\hline Minimum & 0.0000 & 0.0000 & -0.5746 & 0.0132 & -0.0702 & 0.0000 & -33.7520 \\
\hline Std. Dev. & 0.0123 & 0.0370 & 0.0245 & 0.1307 & 0.0066 & 0.4420 & 2.0614 \\
\hline \multicolumn{8}{|c|}{ Cluster 5 High Risk (991 observations) } \\
\hline Mean & 0.0153 & 0.0491 & 0.0066 & 0.6691 & 0.0051 & 0.1775 & -0.7674 \\
\hline Maximum & 0.1400 & 0.3476 & 0.1115 & 0.9040 & 0.0470 & 1.0000 & 130.1400 \\
\hline Minimum & 0.0000 & 0.0000 & -0.1165 & 0.0132 & -0.0702 & 0.0000 & -257.8800 \\
\hline Std. Dev. & 0.0165 & 0.0480 & 0.0189 & 0.1363 & 0.0117 & 0.3823 & 10.4520 \\
\hline \multicolumn{8}{|c|}{ Cluster 6 Low Risk (3535 observations) } \\
\hline Mean & 0.0120 & 0.0429 & -0.0008 & 0.6332 & 0.0087 & 0.3343 & 0.0308 \\
\hline Maximum & 0.1996 & 0.6491 & 0.2941 & 0.9099 & 0.0386 & 1.0000 & 83.3560 \\
\hline Minimum & 0.0000 & 0.0000 & -0.5746 & 0.1234 & -0.0248 & 0.0000 & -33.7520 \\
\hline Std. Dev. & 0.0137 & 0.0511 & 0.0249 & 0.1376 & 0.0044 & 0.4718 & 1.9872 \\
\hline \multicolumn{8}{|c|}{ Cluster 7 High Coverage Ratio (2415 observations) } \\
\hline Mean & 0.0143 & 0.0511 & -0.0036 & 0.5901 & 0.0091 & 0.3987 & -0.0174 \\
\hline Maximum & 0.1996 & 0.6491 & 0.2941 & 0.9099 & 0.0386 & 1.0000 & 20.7920 \\
\hline Minimum & 0.0000 & 0.0000 & -0.5746 & 0.0132 & -0.0675 & 0.0000 & -40.1910 \\
\hline Std. Dev. & 0.0179 & 0.0624 & 0.0282 & 0.1420 & 0.0069 & 0.4897 & 1.6700 \\
\hline \multicolumn{8}{|c|}{ Cluster 8 Low Coverage Ratio (2111 observations) } \\
\hline Mean & 0.0108 & 0.0364 & 0.0065 & 0.6994 & 0.0066 & 0.1871 & -0.2987 \\
\hline Maximum & 0.0658 & 0.2163 & 0.1383 & 0.9040 & 0.0470 & 1.0000 & 130.1400 \\
\hline Minimum & 0.0000 & 0.0000 & -0.0509 & 0.3261 & -0.0702 & 0.0000 & -257.8800 \\
\hline Std. Dev. & 0.0086 & 0.0301 & 0.0149 & 0.1070 & 0.0067 & 0.3900 & 7.5830 \\
\hline \multicolumn{8}{|c|}{$\begin{array}{l}\text { Note. Mean, maximum, minimum and standard deviation are calculated over the sample period } 2001-2012 . L L P_{i, t} \text { is the ratio of Loan Loss } \\
\text { Provisions on Bad Loans to Total Assets. } N P L_{i, t} \text { is the ratio of Bad Loans to Total Loans. } \Delta N P L_{i, t} \text { is the one period ahead first }- \text { difference of } \\
N P L_{i, t} . L O A N_{i, t} \text { is the ratio of Total Loans to Total Assets. } I S_{i, t} \text { is the ratio of earnings before interest, taxes and loan loss provision to total assets. } \\
C A P_{i, t} \text { is a dummy variable that takes value } 1 \text { if the bank has a Tier1 Ratio greater than the level associated to the } 75 \text { th percentile of the sample } \\
\text { distribution and } 0 \text { otherwise. } S I G N_{i, t} \text { is the one - year ahead percentage change of } I S_{i, t} . \\
\text { Source: Authors' calculations using data from ABI (Italian Banking Association). }\end{array}$} \\
\hline
\end{tabular}


Table 5. Results from equations (1-4)

Dependent variable: $L L P_{i, t}$

\begin{tabular}{|c|c|c|c|c|c|c|c|c|}
\hline \multirow{3}{*}{$\begin{array}{l}\text { Regressors } \\
\text { constant }\end{array}$} & & & & & \\
\hline & Equati & on $(1)$ & Equati & on (2) & \multicolumn{2}{|c|}{ Equation (3) } & \multicolumn{2}{|c|}{ Equation (4) } \\
\hline & -0.0086 & $* * *$ & -0.0085 & $* * *$ & -0.0089 & $* * *$ & -0.0086 & $* * *$ \\
\hline$L L P_{i, t-1}$ & -0.0495 & & -0.0425 & & -0.0527 & & -0.0481 & \\
\hline$N P L_{i, t}$ & 0.2455 & $* * *$ & 0.2435 & $* * *$ & 0.2486 & $* * *$ & 0.2457 & $* * *$ \\
\hline$\Delta N P L_{i, t}$ & 0.0052 & & 0.0052 & $* * *$ & 0.0071 & & 0.0052 & \\
\hline$L O A N_{i, t}$ & 0.0164 & $* * *$ & 0.0155 & $* * *$ & 0.0164 & $* * *$ & 0.0164 & $* * *$ \\
\hline$\Delta G D P_{t}$ & 0.0334 & $* * *$ & 0.0317 & $* * *$ & 0.0326 & $* * *$ & 0.0333 & $* * *$ \\
\hline CRISIS $_{t}$ & 0.0008 & $* * *$ & 0.0013 & $* * *$ & 0.0009 & $*$ & 0.0008 & $* * *$ \\
\hline$\Delta G D P_{t} * C R I S I S_{t}$ & -0.0320 & $* * *$ & -0.0302 & $* * *$ & -0.0311 & $* * *$ & -0.0319 & $* * *$ \\
\hline$I S_{i, t}$ & -0.0384 & $* *$ & - & & - & & -0.0377 & $* *$ \\
\hline$I_{i, t} * C^{2} I S I S_{t}$ & - & & -0.0525 & $* * *$ & - & & - & \\
\hline$I_{i, t} * N O C R I S I S_{t}$ & - & & - & & -0.0004 & & - & \\
\hline$C A P_{i, t}$ & 0.0005 & $*$ & 0.0005 & $*$ & 0.0005 & $*$ & 0.0005 & * \\
\hline$S I G N_{i, t}$ & - & & - & & - & & 0.0000 & \\
\hline Observations & 4,328 & & 4,328 & & 4,328 & & 4,327 & \\
\hline Interacted Dummies & Yes & & Yes & & Yes & & Yes & \\
\hline$R^{2}$ & 0.8050 & & 0.8095 & & 0.8050 & & 0.8058 & \\
\hline \# instruments & 54 & & 54 & & 54 & & 55 & \\
\hline VCE robust & yes & & Yes & & Yes & & yes & \\
\hline AR(2) Test (p-value) & 0.4666 & & 0.4195 & & 0.4515 & & 0.4643 & \\
\hline Wald test (p-value) & 0.0000 & & 0.0000 & & 0.0000 & & 0.0000 & \\
\hline
\end{tabular}

Note. The results are from equations (1-4). The dependent variable is the ratio of Loan Loss Provisions on Bad Loans to Total Assets. NPL $L_{i, t}$ is the ratio of Bad Loans to Total Loans. $\triangle N P L_{i, t}$ is the one period ahead first - difference of $N P L_{i, t} . L O A N_{i, t}$ is the ratio of Total Loans to Total Assets. $\triangle G D P_{t}$ is the annual growth of real GDP. CRISIS is a dummy variable that takes value 1 during the period $2008-2012 . \Delta G D P_{t} * C R I S I S_{t}$ is the interactive variable between $\triangle G D P_{t}$ and CRISIS $_{t}$ NOCRISIS $S_{t}$ is a dummy variable that takes value 1 during the period $2001-2007 . S_{i, t}$ is the ratio of earnings before interest, taxes and loan loss provision to total assets. $I S_{i, t}{ }^{*} C R I S I S_{t}$ is the interactive variable between $I S_{i, t}$ and $C R I S I S_{t}$. IS $S_{i, t}{ }^{*}$ NOCRISIS the interactive variable between $I S_{i, t}$ and $C R I S I S_{t}$. CAP $P_{i, t}$ is a dummy variable that takes value 1 if the bank has a Tier1 Ratio greater than that for the 75th percentile of the sample distribution and 0 otherwise. $S I G N_{i, t}$ is the one - year ahead percentage change of $I S_{i, t}$. Definition, sources, number of observations, and preliminary statistics are shown in Tables 1-4.

The regression method is the Arellano-Bond two-step estimator. *, ** and *** indicate statistical significance respectively at the $10 \%$, at $5 \%$ and at $1 \%$ level.

Source: Authors'calculations using data from Istat and ABI (Italian Banking Association). 
Table 6. Results from equations (5) using $\mathrm{HSIZE}_{i, t}$

\begin{tabular}{|c|c|c|c|c|c|c|}
\hline \multirow{3}{*}{$\begin{array}{l}\text { Regressors } \\
\text { constant }\end{array}$} & \multicolumn{6}{|c|}{ Dependent variable: $L L P_{i, t}$} \\
\hline & \multicolumn{2}{|c|}{ Equation (5.1) } & \multicolumn{2}{|c|}{ Equation (5.2) } & \multicolumn{2}{|c|}{ Equation (5.3) } \\
\hline & -0.0089 & $* * *$ & -0.0089 & $* * *$ & -0.0091 & $* * *$ \\
\hline$L L P_{i, t-1}$ & -0.0499 & & -0.0462 & & -0.0509 & \\
\hline$N P L_{i, t}$ & 0.2452 & $* * *$ & 0.2467 & $* * *$ & 0.2484 & $* * *$ \\
\hline$\Delta N P L_{i, t}$ & 0.0070 & & 0.0073 & & 0.0074 & \\
\hline$L O A N_{i, t}$ & 0.0166 & $* * *$ & 0.0163 & $* * *$ & 0.0166 & $* * *$ \\
\hline$\Delta G D P_{t}$ & 0.0322 & $* * *$ & 0.0316 & $* * *$ & 0.0324 & $* * *$ \\
\hline CRISIS $_{t}$ & 0.0008 & $* * *$ & 0.0009 & $* * *$ & 0.0007 & $* * *$ \\
\hline$\Delta G D P_{t} * C R I S I S_{t}$ & -0.0310 & $* * *$ & -0.0303 & $* * *$ & -0.0311 & $* * *$ \\
\hline$C A P_{i, t}$ & 0.0004 & * & 0.0004 & $*$ & 0.0004 & $*$ \\
\hline$H S I Z E_{i, t} * I S_{i, t}$ & -0.0716 & & - & & - & \\
\hline $\operatorname{HSIZE}_{i, t} * \operatorname{IS}_{i, t} * C R I S I S_{t}$ & - & & -0.0355 & & - & \\
\hline HSIZE $_{i, t} * I S_{i, t} * N_{\text {OCRISIS }}$ & - & & - & & -0.0369 & \\
\hline Observations & 4,328 & & 4,328 & & 4,328 & \\
\hline Interacted Dummies & Yes & & Yes & & Yes & \\
\hline$R^{2}$ & 0.8017 & & 0.8075 & & 0.8043 & \\
\hline \# instruments & 54 & & 54 & & 54 & \\
\hline VCE robust & Yes & & Yes & & Yes & \\
\hline AR(2) Test (p-value) & 0.4158 & & 0.4336 & & 0.4469 & \\
\hline Wald test (p-value) & 0.0000 & & 0.0000 & & 0.0000 & \\
\hline \multicolumn{7}{|c|}{ 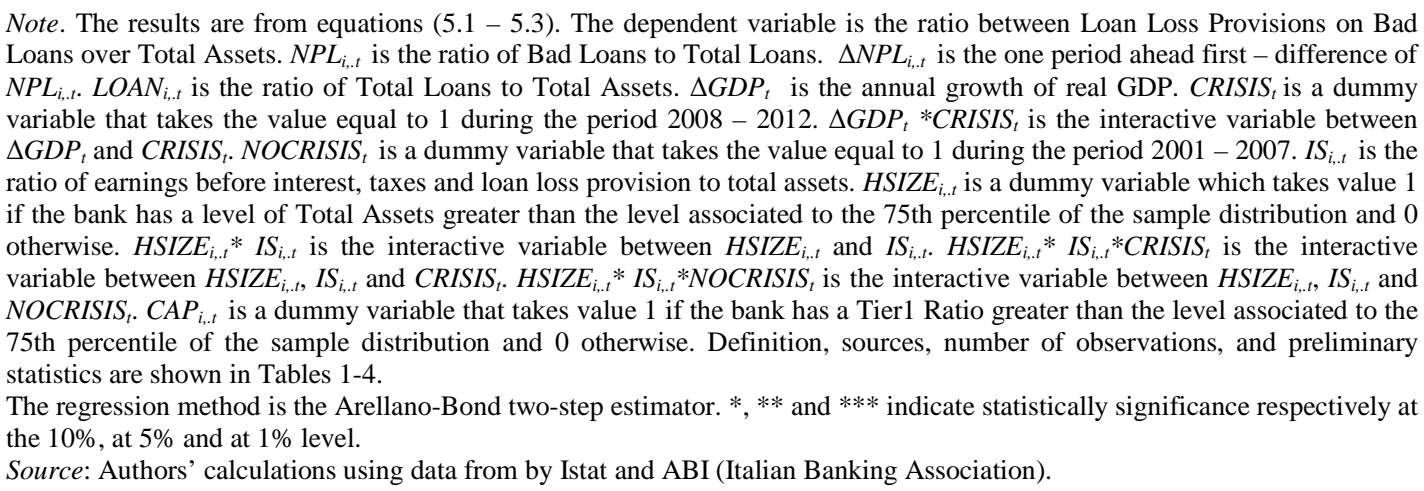 } \\
\hline
\end{tabular}


Table 7. Results from equations (5) using $L_{S I Z E}, t$

Dependent variable: $L L P_{i, t}$

\begin{tabular}{|c|c|c|c|c|c|c|}
\hline \multirow{2}{*}{$\begin{array}{l}\text { Regressors } \\
\text { constant }\end{array}$} & \multicolumn{2}{|c|}{ Equation (5.1) } & \multicolumn{2}{|c|}{ Equation (5.2) } & \multicolumn{2}{|c|}{ Equation (5.3) } \\
\hline & -0.0087 & $* * *$ & -0.0086 & $* * *$ & -0.0090 & $* * *$ \\
\hline$L L P_{i, t-1}$ & -0.0471 & & -0.0434 & & -0.0473 & \\
\hline$N P L_{i, t}$ & 0.2472 & $* * *$ & 0.2465 & $* * *$ & 0.2477 & $* * *$ \\
\hline$\triangle N P L_{i, t}$ & 0.0057 & & 0.0056 & & 0.0071 & \\
\hline$L O A N_{i, t}$ & 0.0162 & $* * *$ & 0.0155 & $* * *$ & 0.0161 & $* * *$ \\
\hline$\Delta G D P_{t}$ & 0.0331 & $* * *$ & 0.0323 & $* * *$ & 0.0321 & $* * *$ \\
\hline CRISIS $_{t}$ & 0.0008 & $* * *$ & 0.0011 & $* * *$ & 0.0010 & $* * *$ \\
\hline$\Delta G D P_{t} * C R I S I S_{t}$ & -0.0319 & $* * *$ & -0.0310 & $* * *$ & -0.0307 & $* * *$ \\
\hline$C A P_{i, t}$ & 0.0005 & $*$ & 0.0004 & $*$ & 0.0005 & * \\
\hline $\operatorname{LSIZE}_{i, t} * I S_{i, t}$ & -0.0212 & & - & & - & \\
\hline $\operatorname{LSIZE}_{i, t}{ }^{*} I_{i, t}{ }^{*} \mathrm{CRISIS}_{t}$ & - & & -0.0465 & $* *$ & - & \\
\hline $\operatorname{LSIZE}_{i, t}{ }^{*} I S_{i, t}{ }^{*} N O C R_{t}$ & - & & - & & 0.0176 & \\
\hline Observations & 4,328 & & 4,328 & & 4,328 & \\
\hline Interacted Dummies & Yes & & Yes & & Yes & \\
\hline$R^{2}$ & 0.8079 & & 0.8099 & & 0.8073 & \\
\hline \# instruments & 54 & & 54 & & 54 & \\
\hline VCE robust & Yes & & Yes & & Yes & \\
\hline AR(2) Test (p-value) & 0.4710 & & 0.4429 & & 0.4350 & \\
\hline Wald test (p-value) & 0.0000 & & 0.0000 & & 0.0000 & \\
\hline
\end{tabular}

Note. The results are from equations $(5.1$ - 5.3). The dependent variable is the ratio between Loan Loss Provisions on Bad Loans over Total Assets. $N P L_{i, t}$ is the ratio of Bad Loans to Total Loans. $\triangle N P L_{i, t}$ is the one period ahead first difference of $N P L_{i, t} . L O A N_{i, t}$ is the ratio of Total Loans to Total Assets. $\triangle G D P_{t}$ is the annual growth of real GDP. CRISIS $_{t}$ is a dummy variable that takes the value equal to 1 during the period $2008-2012 . \Delta G D P_{t} * C R I S I S_{t}$ is the interactive variable between $\Delta G D P_{t}$ and CRISIS $_{t}$ NOCRISIS $_{t}$ is a dummy variable that takes the value equal to 1 during the period $2001-2007 . I S_{i, t}$ is the ratio of earnings before interest, taxes and loan loss provision to total assets. $L S I Z E_{i, t}$ is a dummy variable which takes value 1 if $H S I Z E_{i, t}$ equals to 0,0 otherwise. $L S I Z E_{i, t}{ }^{*} I S_{i, t}$ is the interactive variable

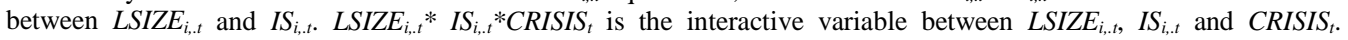
LSIZE $_{i, t} * I S_{i, t} *$ NOCRISIS $_{t}$ is the interactive variable between $\operatorname{LSIZE}_{i, t}, I_{i, t}$ and NOCRISIS . CAP N $_{i, t}$ is a dummy variable that takes value 1 if the bank has a Tier1 Ratio greater than the level associated to the 75th percentile of the sample distribution and 0 otherwise. Definition, sources, number of observations, and preliminary statistics are shown in Tables 1-4.

The regression method is the Arellano-Bond two-step estimator. *, ** and *** indicate statistically significance respectively at the $10 \%$, at $5 \%$ and at $1 \%$ level.

Source: Authors’ calculations using data from by Istat and ABI (Italian Banking Association). 
Table 8. Results from equations (6) using $H G U A_{i, t}$

\begin{tabular}{|c|c|c|c|c|c|c|}
\hline \multirow{3}{*}{$\begin{array}{l}\text { Regressors } \\
\text { constant }\end{array}$} & \multicolumn{6}{|c|}{ Dependent variable: $L L P_{i, t}$} \\
\hline & \multicolumn{2}{|c|}{ Equation (6.1) } & \multicolumn{2}{|c|}{ Equation (6.2) } & \multicolumn{2}{|c|}{ Equation (6.3) } \\
\hline & -0.0088 & $* * *$ & -0.0087 & $* * *$ & -0.0091 & $* * *$ \\
\hline$L L P_{i, t-1}$ & -0.0433 & & -0.0414 & & -0.0473 & \\
\hline$N P L_{i, t}$ & 0.2465 & $* * *$ & 0.2447 & $* * *$ & 0.2481 & $* * *$ \\
\hline$\triangle N P L_{i, t}$ & 0.0072 & & 0.0072 & & 0.0070 & \\
\hline$L O A N_{i, t}$ & 0.0163 & $* * *$ & 0.0160 & $* * *$ & 0.0164 & $* * *$ \\
\hline$\Delta G D P_{t}$ & 0.0317 & $* * *$ & 0.0321 & $* * *$ & 0.0324 & $* * *$ \\
\hline CRISIS $_{t}$ & 0.0008 & $* * *$ & 0.0010 & $* * *$ & 0.0009 & $* * *$ \\
\hline$\Delta G D P_{t} * C^{*} I S I S_{t}$ & -0.0306 & $* * *$ & -0.0312 & $* * *$ & -0.0311 & $* * *$ \\
\hline$C A P_{i, t}$ & 0.0004 & $*$ & 0.0005 & $*$ & 0.0005 & $*$ \\
\hline$H G U A_{i, t} * I S_{i, t}$ & -0.0334 & $*$ & - & & - & \\
\hline 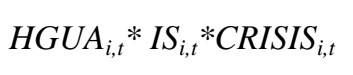 & - & & -0.0906 & $* * *$ & - & \\
\hline$H G U A_{i, t} * I S_{i, t} * N O C R_{t}$ & - & & - & & 0.0273 & \\
\hline Observations & 4,328 & & 4,328 & & 4,328 & \\
\hline Interacted Dummies & Yes & & Yes & & Yes & \\
\hline$R^{2}$ & 0.8078 & & 0.8084 & & 0.8078 & \\
\hline \# instruments & 54 & & 54 & & 54 & \\
\hline VCE robust & Yes & & Yes & & Yes & \\
\hline AR(2) Test ( $p$-value) & 0.4328 & & 0.4392 & & 0.4617 & \\
\hline Wald test (p-value) & 0.0000 & & 0.0000 & & 0.0000 & \\
\hline \multicolumn{7}{|c|}{ 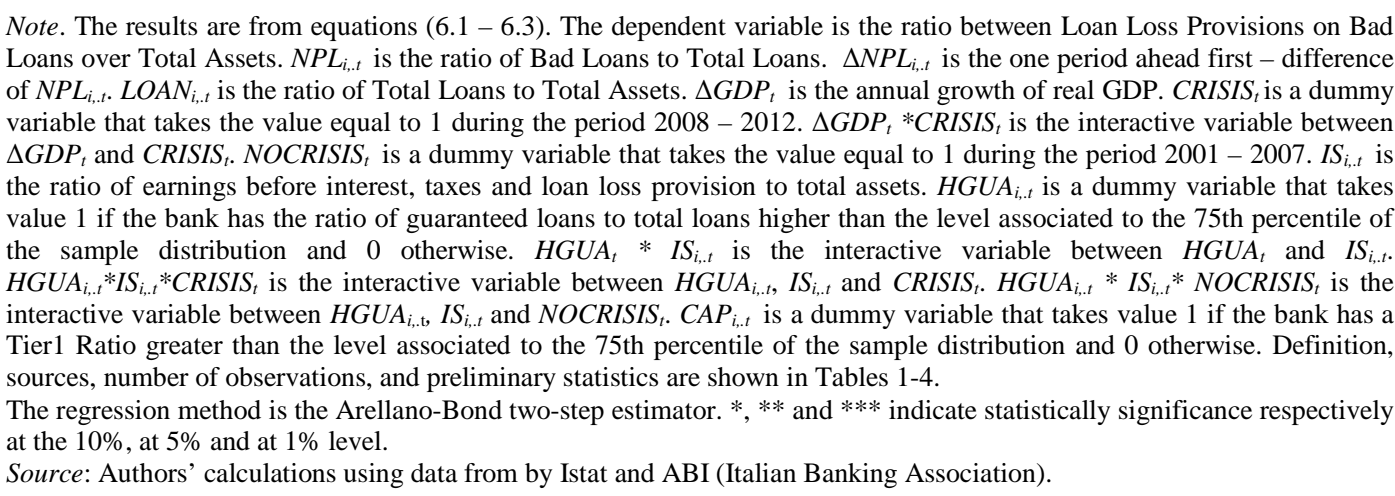 } \\
\hline
\end{tabular}


Table 9. Results from equations (6) using $L G U A_{i, t}$

\section{Dependent variable: $L L P_{i, t}$}

\begin{tabular}{|c|c|c|c|c|c|c|}
\hline \multirow{2}{*}{$\begin{array}{l}\text { Regressors } \\
\text { constant }\end{array}$} & \multicolumn{2}{|c|}{ Equation (6.1) } & \multicolumn{2}{|c|}{ Equation (6.2) } & \multicolumn{2}{|c|}{ Equation (6.3) } \\
\hline & -0.0090 & $* * *$ & -0.0089 & $* * *$ & -0.0090 & $* * *$ \\
\hline$L L P_{i, t-1}$ & -0.0518 & & -0.0456 & & -0.0527 & \\
\hline$N P L_{i, t}$ & 0.2472 & $* * *$ & 0.2467 & $* * *$ & 0.2485 & $* * *$ \\
\hline$\Delta N P L_{i, t}$ & 0.0060 & & 0.0063 & & 0.0070 & \\
\hline$L O A N_{i, t}$ & 0.0167 & $* * *$ & 0.0162 & $* * *$ & 0.0166 & $* * *$ \\
\hline$\Delta G D P_{t}$ & 0.0328 & $* * *$ & 0.0314 & $* * *$ & 0.0329 & $* * *$ \\
\hline CRISIS $_{t}$ & 0.0007 & $* * *$ & 0.0010 & $* * *$ & 0.0007 & $* *$ \\
\hline$\Delta G D P_{t} * C R I S I S_{t}$ & -0.0315 & $* * *$ & -0.0300 & $* * *$ & -0.0316 & $* * *$ \\
\hline$C A P_{i, t}$ & 0.0004 & $*$ & 0.0004 & $*$ & 0.0004 & $*$ \\
\hline$L G U A_{i, t} * I S_{i, t}$ & -0.0237 & & - & & - & \\
\hline $\operatorname{LGUA}_{i, t} * I_{i, t} * \mathrm{CRISIS}_{t}$ & - & & -0.0245 & & - & \\
\hline$L G U A_{i, t} * I S_{i, t} * N O C R_{t}$ & - & & - & & -0.0128 & \\
\hline Observations & 4,328 & & 4,328 & & 4,328 & \\
\hline Interacted Dummies & Yes & & Yes & & Yes & \\
\hline$R^{2}$ & 0.8051 & & 0.8084 & & 0.8046 & \\
\hline \# instruments & 54 & & 54 & & 54 & \\
\hline VCE robust & Yes & & Yes & & Yes & \\
\hline AR(2) Test (p-value) & 0.4669 & & 0.4367 & & 0.4655 & \\
\hline Wald test (p-value) & 0.0000 & & 0.0000 & & 0.0000 & \\
\hline
\end{tabular}

Note. The results are from equations $(6.1-6.3)$. The dependent variable is the ratio between Loan Loss Provisions on Bad Loans over Total Assets. $N P L_{i, t}$ is the ratio of Bad Loans to Total Loans. $\triangle N P L_{i, t}$ is the one period ahead first - difference

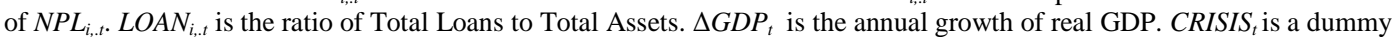
variable that takes the value equal to 1 during the period $2008-2012 . \Delta G D P_{t}{ }^{*} C R I S I S_{t}$ is the interactive variable between $\Delta G D P_{t}$ and CRISIS $_{t}$ NOCRISIS $_{t}$ is a dummy variable that takes the value equal to 1 during the period $2001-2007 . S_{i, t}$ is the ratio of earnings before interest, taxes and loan loss provision to total assets. $L G U A_{i, t}$ is a dummy variable that takes value 1 if the bank has the ratio of guaranteed loans to total loans lower than the level associated to the 75th percentile of the sample distribution and 0 otherwise. $L G U A_{i, t} * I S_{i, t}$ is the interactive variable between $L G U A_{i, t}$ and $I S_{i, t}$. $L_{G U A_{i, t}} * I S_{i, t} *{ }^{*} R I S I S_{t}$ is the interactive variable between $L G U A_{i, t}, I S_{i, t}$ and CRISIS LGUA $_{i, t} * \operatorname{IS}_{i, t} *$ NOCRISIS $_{t}$ is the interactive variable between $L G U A_{i, t}, I S_{i, t}$ and NOCRISIS . CAP $_{i, t}$ is a dummy variable that takes value 1 if the bank has a Tier1 Ratio greater than the level associated to the 75th percentile of the sample distribution and 0 otherwise. Definition, sources, number of observations, and preliminary statistics are shown in Tables 1-4.

The regression method is the Arellano-Bond two-step estimator. *, ** and *** indicate statistically significance respectively at the $10 \%$, at $5 \%$ and at $1 \%$ level.

Source: Authors' calculations using data from by Istat and ABI (Italian Banking Association). 
Table 10. Results from equations (7) using $H C R_{i, t}$

Dependent variable: $L L P_{i, t}$

\begin{tabular}{|c|c|c|c|c|c|c|}
\hline \multirow{2}{*}{$\begin{array}{l}\text { Regressors } \\
\text { constant }\end{array}$} & \multicolumn{2}{|c|}{ Equation (7.1) } & \multicolumn{2}{|c|}{ Equation (7.2) } & \multicolumn{2}{|c|}{ Equation (7.3) } \\
\hline & -0.0087 & $* * *$ & -0.0090 & $* * *$ & -0.0086 & $* * *$ \\
\hline$L L P_{i, t-1}$ & -0.0435 & & -0.0452 & & -0.0437 & \\
\hline$N P L_{i, t}$ & 0.2500 & $* * *$ & 0.2473 & $* * *$ & 0.2494 & $* * *$ \\
\hline$\Delta N P L_{i, t}$ & 0.0073 & & 0.0073 & & 0.0076 & \\
\hline$L O A N_{i, t}$ & 0.0161 & $* * *$ & 0.0164 & $* * *$ & 0.0161 & $* * *$ \\
\hline$\Delta G D P_{t}$ & 0.0263 & $* * *$ & 0.0320 & $* * *$ & 0.0260 & $* * *$ \\
\hline CRISIS $_{t}$ & 0.0007 & $* * *$ & 0.0008 & $* * *$ & 0.0007 & $* * *$ \\
\hline$\Delta G D P_{t} * C^{2} I S I S_{t}$ & -0.0250 & $* * *$ & -.00308 & $* * *$ & -0.0247 & $* * *$ \\
\hline$C A P_{i, t}$ & 0.0004 & $*$ & 0.0004 & $*$ & 0.0004 & $*$ \\
\hline$H C R_{i, t} * I S_{i, t}$ & -0.0232 & & - & & - & \\
\hline $\operatorname{HCR}_{i, t} *{ }^{*} S_{i, t}{ }^{*} C R I S I S_{t}$ & - & & 0.0312 & & - & \\
\hline$H C R_{i, t} * I S_{i, t} * N O C R_{t}$ & - & & - & & -0.0252 & \\
\hline Observations & 4,328 & & 4,328 & & 4,328 & \\
\hline Interacted Dummies & Yes & & Yes & & Yes & \\
\hline$R^{2}$ & 0.8094 & & 0.8086 & & 0.8095 & \\
\hline \# instruments & 54 & & 54 & & 54 & \\
\hline VCE robust & Yes & & Yes & & Yes & \\
\hline AR(2) Test (p-value) & 0.4819 & & 0.4423 & & 0.4742 & \\
\hline Wald test (p-value) & 0.0000 & & 0.0000 & & 0.0000 & \\
\hline
\end{tabular}

Note. The results are from equations $(7.1$ - 7.3). The dependent variable is the ratio between Loan Loss Provisions on Bad Loans over Total Assets. $N P L_{i, t}$ is the ratio of Bad Loans to Total Loans. $\triangle N P L_{i, t}$ is the one period ahead first - difference of $N P L_{i, t} . L O A N_{i, t}$ is the ratio of Total Loans to Total Assets. $\triangle G D P_{t}$ is the annual growth of real GDP. CRISIS is a dummy variable that takes the value equal to 1 during the period $2008-2012 . \Delta G D P_{t}{ }^{*} C R I S I S_{t}$ is the interactive variable between $\triangle G D P_{t}$ and CRISIS $_{t}$. NOCRISIS ${ }_{t}$ is a dummy variable that takes the value equal to 1 during the period $2001-2007 . I S_{i, t}$ is the ratio of earnings before interest, taxes and loan loss provision to total assets. $H C R_{i, t}$ is a dummy variable that takes value 1 if the bank has a coverage ratio higher than the level associated to the 75th percentile of the sample distribution and 0 otherwise. $H C R_{i, t} * I S_{i, t}$ is the interactive variable between $H C R_{i, t}$ and $I S_{i, t} . H C R_{i, t} * I S_{i, t} * C R I S I S_{t}$ is the interactive variable between $H C R_{i, t}, I S_{i, t}$ and $C R I S I S_{t} . H C R_{i, t} * I S_{i, t} * N O C R I S I S_{t}$ is the interactive variable between $H_{C} R_{i, t}, I_{i, t}$ and $N O C R I S I S_{t}$. $C A P_{i, t}$ is a dummy variable that takes value 1 if the bank has a Tier1 Ratio greater than the level associated to the 75th percentile of the sample distribution and 0 otherwise. Definition, sources, number of observations, and preliminary statistics are shown in Tables 1-4.

The regression method is the Arellano-Bond two-step estimator. *, ** and *** indicate statistically significance respectively at the $10 \%$, at $5 \%$ and at $1 \%$ level.

Source: Authors' calculations using data from by Istat and ABI (Italian Banking Association). 
Table 11. Results from equations (7) using $L C R_{i, t}$

\begin{tabular}{|c|c|c|c|c|c|c|}
\hline \multirow{3}{*}{$\begin{array}{l}\text { Regressors } \\
\text { constant }\end{array}$} & \multicolumn{6}{|c|}{ Dependent variable: $L L P_{i, t}$} \\
\hline & \multicolumn{2}{|c|}{ Equation (7.1) } & \multicolumn{2}{|c|}{ Equation (7.2) } & \multicolumn{2}{|c|}{ Equation (7.3) } \\
\hline & -0.0089 & $* * *$ & -0.0084 & $* * *$ & -0.0085 & $* * *$ \\
\hline$L L P_{i, t-1}$ & -0.0537 & & -0.0416 & & -0.0506 & \\
\hline$N P L_{i, t}$ & 0.2455 & $* * *$ & 0.2427 & $* * *$ & 0.2492 & $* * *$ \\
\hline$\Delta N P L_{i, t}$ & 0.0057 & & 0.0052 & & 0.0077 & \\
\hline$L O A N_{i, t}$ & 0.0165 & $* * *$ & 0.0155 & $* * *$ & 0.0155 & $* * *$ \\
\hline$\Delta G D P_{t}$ & 0.0359 & $* * *$ & 0.0316 & $* * *$ & 0.0259 & $* * *$ \\
\hline CRISIS $_{t}$ & 0.0008 & $* * *$ & 0.0013 & $* * *$ & 0.0010 & $* * *$ \\
\hline$\Delta G D P_{t} * C R I S I S_{t}$ & -0.0347 & $* * *$ & -0.0301 & $* * *$ & -0.0243 & $* * *$ \\
\hline$C A P_{i, t}$ & 0.0004 & $*$ & 0.0004 & $*$ & 0.0004 & $* *$ \\
\hline$L C R_{i, t} * I S_{i, t}$ & -0.0162 & & - & & - & \\
\hline $\operatorname{LCR}_{i, t} * \operatorname{IS}_{i, t} * C R I S I S_{t}$ & - & & -0.0539 & $* * *$ & - & \\
\hline$L C R_{i, t} * I S_{i, t} * N O C R_{t}$ & - & & - & & 0.0260 & * \\
\hline Observations & 4,328 & & 4,328 & & 4,328 & \\
\hline Interacted Dummies & Yes & & Yes & & Yes & \\
\hline$R^{2}$ & 0.8037 & & 0.8105 & & & \\
\hline \# instruments & 54 & & 54 & & 54 & \\
\hline VCE robust & Yes & & Yes & & Yes & \\
\hline AR(2) Test (p-value) & 0.4403 & & 0.4088 & & 0.4514 & \\
\hline Wald test ( $p$-value) & 0.0000 & & 0.0000 & & 0.0000 & \\
\hline \multicolumn{7}{|c|}{ 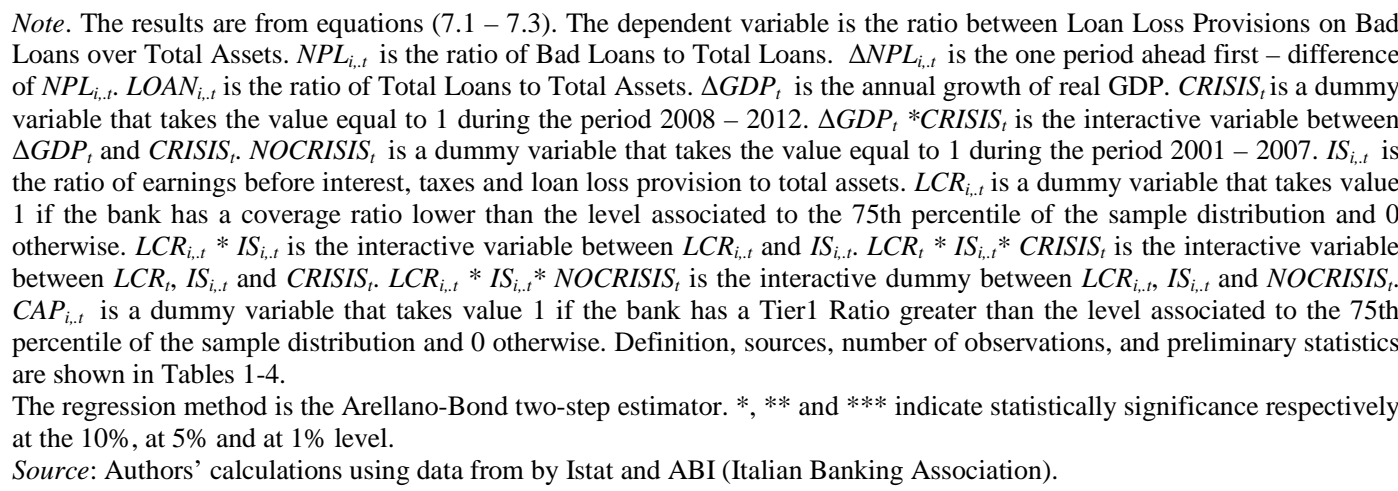 } \\
\hline
\end{tabular}


Table 12. Equation (8) using HRISK $_{i, t}$

\section{Dependent variable: $L L P_{i, t}$}

\begin{tabular}{|c|c|c|c|c|c|c|}
\hline \multirow{2}{*}{$\begin{array}{l}\text { Regressors } \\
\text { constant }\end{array}$} & \multicolumn{2}{|c|}{ Equation (8.1) } & \multicolumn{2}{|c|}{ Equation (8.2) } & \multicolumn{2}{|c|}{ Equation (8.3) } \\
\hline & -0.0090 & $* * *$ & -0.0084 & $* * *$ & -0.0089 & $* * *$ \\
\hline$L L P_{i, t-1}$ & -0.0439 & & -0.0434 & & -0.0462 & \\
\hline$N P L_{i, t}$ & 0.2458 & $* * *$ & 0.2443 & $* * *$ & 0.2477 & $* * *$ \\
\hline$\Delta N P L_{i, t}$ & 0.0073 & & 0.0068 & & 0.0072 & \\
\hline$L O A N_{i, t}$ & 0.0165 & $* * *$ & 0.0155 & $* * *$ & 0.0162 & $* * *$ \\
\hline$\Delta G D P_{t}$ & 0.0299 & $* * *$ & 0.0311 & $* * *$ & 0.0318 & $* * *$ \\
\hline CRISIS $_{t}$ & 0.0007 & $* * *$ & 0.0011 & $* * *$ & 0.0008 & $* * *$ \\
\hline$\Delta G D P_{t} * C R I S I S_{t}$ & -0.0288 & $* * *$ & -0.0300 & $* * *$ & -0.0305 & $* * *$ \\
\hline$C A P_{i, t}$ & 0.0004 & $*$ & 0.0005 & $*$ & 0.0004 & $*$ \\
\hline HRISK $_{i, t} * I S_{i, t}$ & -0.0351 & $* * *$ & - & & - & \\
\hline HRISK $_{i, t}{ }^{*}$ IS $_{i, t}{ }^{*}$ CRISIS $_{t}$ & - & & -0.0601 & $* * *$ & - & \\
\hline HRISK $_{i, t} * I S_{i, t} * N_{O C C}$ & - & & - & & -0.0004 & \\
\hline Observations & 4,328 & & 4,328 & & 4,328 & \\
\hline Interacted Dummies & Yes & & Yes & & Yes & \\
\hline$R^{2}$ & 0.8082 & & 0.8097 & & 0.8079 & \\
\hline \# instruments & 54 & & 54 & & 54 & \\
\hline VCE robust & Yes & & Yes & & Yes & \\
\hline AR(2) Test (p-value) & 0.4519 & & 0.4079 & & 0.4512 & \\
\hline Wald test (p-value) & 0.0000 & & 0.0000 & & 0.0000 & \\
\hline
\end{tabular}

Note. The results are from equations $(8.1$ - 8.3). The dependent variable is the ratio between Loan Loss Provisions on Bad Loans over Total Assets. $N P L_{i, t}$ is the ratio of Bad Loans to Total Loans. $\triangle N P L_{i, t}$ is the one period ahead first - difference

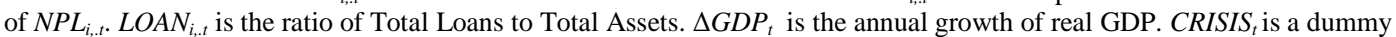
variable that takes the value equal to 1 during the period $2008-2012 . \Delta G D P_{t}{ }^{*} C R I S I S_{t}$ is the interactive variable between $\triangle G D P_{t}$ and CRISIS $_{t}$. NOCRISIS ${ }_{t}$ is a dummy variable that takes the value equal to 1 during the period $2001-2007 . S_{i, t}$ is the ratio of earnings before interest, taxes and loan loss provision to total assets. RISK $_{i, t}$ is the standard deviation of adjusted Return on Equity, computed using 3-year rolling windows. HRISK $K_{i, t}$ is a dummy variable which takes value of 1 if $R I S K_{i, t}$ for the i-th bank is greater than the value associated to the $75^{\text {th }}$ percentile of the sample distribution and 0 otherwise. HRISK $_{i, t} * I S_{i, t}$ is the interactive dummy between HRISK $_{i, t}$ and $I S_{i, t} . H_{R I S K} K_{i, t} * I_{i, t} *$ CRISIS $_{t}$ is the interactive dummy between HRISK ${ }_{i, t}, I_{i, t}$ and CRISIS . HRISK $_{i, t} * I_{i, t} *$ NOCRISIS $_{t}$ is the interactive dummy between HRISK $K_{i, t}$ IS $S_{i, t}$ and CRISIS $_{t}$. CAP $P_{i, t}$ is a dummy variable that takes value 1 if the bank has a Tier1 Ratio greater than the level associated to the 75th percentile of the sample distribution and 0 otherwise. Definition, sources, number of observations, and preliminary statistics are shown in Tables 1-4.

The regression method is the Arellano-Bond two-step estimator. * $* *$ and *** indicate statistically significance respectively at the $10 \%$, at $5 \%$ and at $1 \%$ level.

Source: Authors' calculations using data from by Istat and ABI (Italian Banking Association). 
Table 13. Results from equations (8) using $L_{R I S K}$

\section{Dependent variable: $L L P_{i, t}$}

\begin{tabular}{|c|c|c|c|c|c|c|}
\hline \multirow{2}{*}{$\begin{array}{l}\text { Regressors } \\
\text { constant }\end{array}$} & \multicolumn{2}{|c|}{ Equation (8.1) } & \multicolumn{2}{|c|}{ Equation (8.2) } & \multicolumn{2}{|c|}{ Equation (8.3) } \\
\hline & -0.0091 & $* * *$ & -0.0091 & $* * *$ & -0.0090 & $* * *$ \\
\hline$L L P_{i, t-1}$ & -0.0452 & & -0.0452 & & -0.0446 & \\
\hline$N P L_{i, t}$ & 0.2481 & $* * *$ & 0.2485 & $* * *$ & 0.2479 & $* * *$ \\
\hline$\Delta N P L_{i, t}$ & 0.0064 & & 0.0070 & & 0.0070 & \\
\hline $\operatorname{LOAN}_{i, t}$ & 0.0165 & $* * *$ & 0.0164 & $* * *$ & 0.0164 & $* * *$ \\
\hline$\Delta G D P_{t}$ & 0.0321 & $* * *$ & 0.0320 & $* * *$ & 0.0319 & $* * *$ \\
\hline CRISIS $_{i, t}$ & 0.0008 & $* * *$ & 0.0009 & $* * *$ & 0.0008 & $* * *$ \\
\hline$\Delta G D P_{t} * C R I S I S_{t}$ & -0.0309 & $* * *$ & -0.0307 & $* * *$ & -0.0306 & $* * *$ \\
\hline$C A P_{i, t}$ & 0.0004 & $*$ & 0.0004 & * & 0.0004 & $*$ \\
\hline LRISK $_{i, t} * I S_{i, t}$ & -0.0027 & & - & & - & \\
\hline LRISK $_{i, t} * I_{i, t} *{ }^{*}$ RISIS $_{t}$ & - & & -0.0064 & & - & \\
\hline $\operatorname{LRISK}_{i, t} * I S_{i, t} * N O C R_{t}$ & - & & - & & -0.0020 & \\
\hline Observations & 4,328 & & 4,328 & & 4,328 & \\
\hline Interacted Dummies & Yes & & Yes & & Yes & \\
\hline$R^{2}$ & 0.8081 & & 0.8084 & & & \\
\hline \# instruments & 54 & & 54 & & 54 & \\
\hline VCE robust & Yes & & Yes & & Yes & \\
\hline AR(2) Test (p-value) & 0.4559 & & 0.4526 & & 0.4514 & \\
\hline Wald test (p-value) & 0.0000 & & 0.0000 & & 0.0000 & \\
\hline \multicolumn{7}{|c|}{$\begin{array}{l}\text { Note. The results are from equations (8.1- 8.3). The dependent variable is the ratio between Loan Loss Provisions on Bad } \\
\text { Loans over Total Assets. } N P L_{i, t} \text { is the ratio of Bad Loans to Total Loans. } \Delta N P L_{i, t} \text { is the one period ahead first - difference } \\
\text { of } N P L_{i, t} . \\
\text { varian }\end{array}$} \\
\hline
\end{tabular}


Table 14. Results from equations (9)

Dependent variable: $L L P_{i, t}$

\begin{tabular}{|c|c|c|c|c|c|c|c|c|}
\hline \multirow{3}{*}{$\begin{array}{l}\text { Regressors } \\
\text { constant }\end{array}$} & & & & & & & & \\
\hline & \multicolumn{2}{|c|}{ Equation (9.1) } & \multicolumn{2}{|c|}{ Equation (9.2) } & \multicolumn{2}{|c|}{ Equation (9.3) } & \multicolumn{2}{|c|}{ Equation (9.4) } \\
\hline & -0.0088 & $* * *$ & -0.0088 & $* * *$ & -0.0088 & $* * *$ & -0.0089 & $* * *$ \\
\hline$L L P_{i, t-1}$ & -0.0463 & & -0.0448 & & -0.0421 & & -0.0476 & \\
\hline$N P L_{i, t}$ & 0.2463 & $* * *$ & 0.2464 & $* * *$ & 0.2452 & $* * *$ & 0.2478 & $* * *$ \\
\hline$\Delta N P L_{i, t}$ & 0.0049 & & 0.0049 & & 0.0040 & & 0.0074 & \\
\hline$L O A N_{i, t}$ & 0.0164 & $* * *$ & 0.0164 & $* * *$ & 0.0159 & $* * *$ & 0.0159 & $* * *$ \\
\hline$\Delta G D P_{t}$ & 0.0323 & $* * *$ & 0.0322 & $* * *$ & 0.0317 & $* * *$ & 0.0318 & $* * *$ \\
\hline CRISIS $_{t}$ & 0.0008 & $* * *$ & 0.0008 & $* * *$ & 0.0013 & $* * *$ & 0.0010 & $* * *$ \\
\hline$\Delta G D P_{t} * C R I S I S_{t}$ & -0.0310 & $* * *$ & -0.0309 & $* * *$ & -0.0302 & $* * *$ & -0.0304 & $* * *$ \\
\hline$I S_{i, t} * L O C A L_{i, t}$ & -0.0333 & $* *$ & -0.0324 & $* *$ & - & & - & \\
\hline$I_{i, t} * \operatorname{LOCAL}_{i, t} *$ CRISIS $_{t}$ & - & & - & & -0.0760 & $* * *$ & - & \\
\hline$I_{i, t} * \operatorname{LOCAL}_{i, t} *$ NOCRISIS $_{t}$ & - & & - & & - & & 0.0241 & \\
\hline$C A P_{i, t}$ & 0.0004 & * & 0.0004 & * & 0.0004 & $*$ & 0.0004 & * \\
\hline$S I G N_{i, t}$ & - & & 0.0000 & & - & & - & \\
\hline Observations & 4,328 & & 4,327 & & 4,328 & & 4,328 & \\
\hline Interacted Dummies & yes & & Yes & & Yes & & yes & \\
\hline$R^{2}$ & 0.8082 & & 0.8089 & & 0.8101 & & 0.8071 & \\
\hline \# instruments & 54 & & 55 & & 54 & & 54 & \\
\hline VCE robust & Yes & & Yes & & Yes & & Yes & \\
\hline AR(2) Test ( $p$-value) & 0.4757 & & 0.4729 & & 0.4293 & & 0.4313 & \\
\hline Wald test ( $p$-value) & 0.0000 & & 0.0000 & & 0.0000 & & 0.0000 & \\
\hline
\end{tabular}

Note. The results are from equations $(9.1$ - 9.4). The dependent variable is the ratio between Loan Loss Provisions on Bad Loans over Total Assets. $N P L_{i, t}$ is the ratio of Bad Loans to Total Loans. $\triangle N P L_{i, t}$ is the one period ahead first - difference of $N P L_{i, t} . L O A N_{i, t}$ is the ratio of Total Loans to Total Assets. $\triangle G D P_{t}$ is the annual growth of real GDP. CRISIS $S_{t}$ is a dummy variable that takes the value equal to 1 during the period $2008-2012$. $\Delta G D P_{t}{ }^{*} C R I S I S_{t}$ is the interactive variable between $\Delta G D P_{t}$ and $C_{R I S I S}$. NOCRISIS $S_{t}$ is a dummy variable that takes the value equal to 1 during the period $2001-2007 . I S_{i, t}$ is the ratio of earnings before interest, taxes and loan loss provision to total assets. $L O C A L_{i, t}$ is a dummy variable that takes value 1 if the bank is a Local Bank and 0 otherwise. $I S_{i, t} * L O C A L_{i, t}$ is the interactive dummy between $I S_{i, t}$ and $L O C A L_{i, t .}$. IS $S_{i, t} * L O C A L_{i, t} * C R I S I S_{t}$ is the interactive dummy between $I S_{i, t}$, LOCAL $L_{i, t}$ and CRISIS $I_{t} I S_{i, t}{ }^{*} L O C A L_{i, t} * N O C R I S I S_{t}$ is the interactive dummy between $I S_{i, t}$, $L O C A L_{i, t}$ and NOCRISIS $_{t}$. CAP $P_{i, t}$ is a dummy variable that takes value 1 if the bank has a Tier1 Ratio greater than the level associated to the 75 th percentile of the sample distribution and 0 otherwise. Definition, sources, number of observations, and preliminary statistics are shown in Tables 1-4.

The regression method is the Arellano-Bond two-step estimator. *, ** and *** indicate statistically significance respectively at the $10 \%$, at $5 \%$ and at $1 \%$ level.

Source: Authors’ calculations using data from by Istat and ABI (Italian Banking Association). 
Table 15. Results from equations (10) using $H G U A_{i, t}$

\section{Dependent variable: $L L P_{i, t}$}

\begin{tabular}{|c|c|c|c|c|c|c|}
\hline \multirow{2}{*}{$\begin{array}{l}\text { Regressors } \\
\text { constant }\end{array}$} & \multicolumn{2}{|c|}{ Equation (10.1) } & \multicolumn{2}{|c|}{ Equation (10.2) } & \multicolumn{2}{|c|}{ Equation (10.3) } \\
\hline & -0.0088 & $* * *$ & -0.0087 & $* * *$ & -0.0090 & $* * *$ \\
\hline$L L P_{i, t-1}$ & -0.0426 & & -0.0405 & & -0.0469 & \\
\hline$N P L_{i, t}$ & 0.2461 & $* * *$ & 0.2447 & $* * *$ & 0.2482 & $* * *$ \\
\hline$\triangle N P L_{i, t}$ & 0.0073 & & 0.0074 & & 0.0070 & \\
\hline$L O A N_{i, t}$ & 0.0162 & $* * *$ & 0.0159 & $* * *$ & 0.0163 & $* * *$ \\
\hline$\Delta G D P_{t}$ & 0.0316 & $* * *$ & 0.0322 & $* * *$ & 0.0323 & $* * *$ \\
\hline CRISIS $_{t}$ & 0.0008 & $* * *$ & 0.0010 & $* * *$ & 0.0008 & $* * *$ \\
\hline$\Delta G D P_{t} * C_{R I S I S}$ & -0.0306 & $* * *$ & -0.0315 & $* * *$ & -0.0310 & $* * *$ \\
\hline$C A P_{i, t}$ & 0.0004 & $*$ & 0.0004 & * & 0.0004 & * \\
\hline$H G U A_{i, t} * I S_{i, t} * L O C A L_{i, t}$ & -0.0398 & $*$ & - & & - & \\
\hline $\operatorname{HGUA}_{i, t} * I S_{i, t} * L^{2 O C A L_{i, t}} *$ CRISIS $_{t}$ & - & & -0.1010 & $* * *$ & - & \\
\hline $\operatorname{HGUA}_{i, t} * I S_{i, t} * L O C A L_{i, t} * N O C R_{t}$ & - & & - & & 0.0231 & \\
\hline Observations & 4,328 & & 4,328 & & 4,328 & \\
\hline Interacted Dummies & Yes & & Yes & & Yes & \\
\hline$R^{2}$ & 0.8083 & & 0.8092 & & 0.8078 & \\
\hline \# instruments & 54 & & 54 & & 54 & \\
\hline VCE robust & Yes & & Yes & & Yes & \\
\hline AR(2) Test (p-value) & 0.4291 & & 0.4319 & & 0.4591 & \\
\hline Wald test (p-value) & 0.0000 & & 0.0000 & & 0.0000 & \\
\hline \multicolumn{7}{|c|}{ 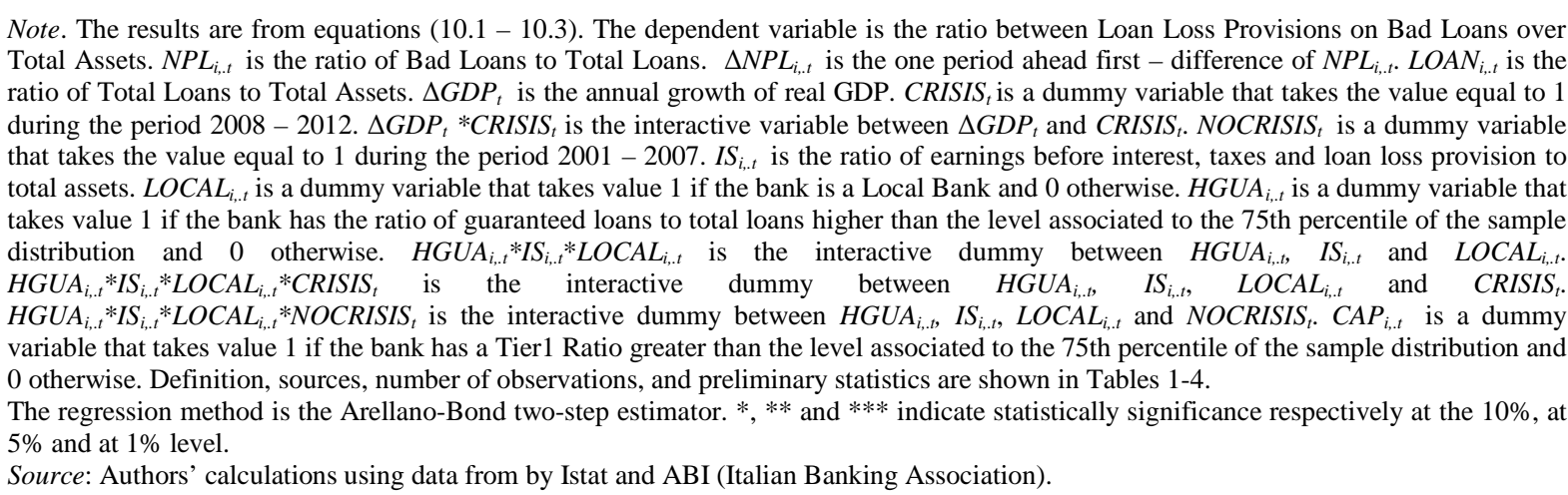 } \\
\hline
\end{tabular}


Table 16. Results from equations (10) using $L G U A_{i, t}$

\section{Dependent variable: $L L P_{i, t}$}

\begin{tabular}{|c|c|c|c|c|c|c|}
\hline \multirow{2}{*}{$\begin{array}{l}\text { Regressors } \\
\text { constant }\end{array}$} & \multicolumn{2}{|c|}{ Equation (10.1) } & \multicolumn{2}{|c|}{ Equation (10.2) } & \multicolumn{2}{|c|}{ Equation (10.3) } \\
\hline & -0.0091 & $* * *$ & -0.0090 & $* * *$ & -0.0091 & $* * *$ \\
\hline$L L P_{i, t-1}$ & -0.0483 & & -0.0457 & & -0.0469 & \\
\hline$N P L_{i, t}$ & 0.2484 & $* * *$ & 0.2482 & $* * *$ & 0.2482 & $* * *$ \\
\hline$\triangle N P L_{i, t}$ & 0.0062 & & 0.0059 & & 0.0070 & \\
\hline$L O A N_{i, t}$ & 0.0166 & $* * *$ & 0.0163 & $* * *$ & 0.0163 & $* * *$ \\
\hline$\Delta G D P_{t}$ & 0.0320 & $* * *$ & 0.0314 & $* * *$ & 0.0323 & $* * *$ \\
\hline CRISIS $_{t}$ & 0.0008 & $* * *$ & 0.0010 & $* * *$ & 0.0008 & $* * *$ \\
\hline$\Delta G D P_{t} * C^{2} I S I S_{t}$ & -0.0307 & $* * *$ & -0.0299 & $* * *$ & -0.0310 & $* * *$ \\
\hline$C A P_{i, t}$ & 0.0004 & * & 0.0004 & $*$ & 0.0004 & $*$ \\
\hline$L G U A_{i, t} * I S_{i, t} * L O C A L_{t}$ & -0.0092 & & - & & - & \\
\hline $\operatorname{LGUA}_{i, t} * \operatorname{IS}_{i, t} * \operatorname{LOCAL}_{i, t} * \operatorname{CRISIS}_{t}$ & - & & -0.0337 & & - & \\
\hline $\operatorname{LGUA}_{i, t} * I_{i, t}{ }^{*} \operatorname{LOCAL}_{i, t} *$ NOCRISIS $_{t}$ & - & & - & & 0.0231 & \\
\hline Observations & 4,328 & & 4,328 & & 4,328 & \\
\hline Interacted Dummies & Yes & & Yes & & Yes & \\
\hline$R^{2}$ & 0.8071 & & 0.8088 & & 0.8078 & \\
\hline \# instruments & 54 & & 54 & & 54 & \\
\hline VCE robust & Yes & & Yes & & Yes & \\
\hline AR(2) Test (p-value) & 0.4665 & & 0.4463 & & 0.4591 & \\
\hline Wald test (p-value) & 0.0000 & & 0.0000 & & 0.0000 & \\
\hline
\end{tabular}

Note. The results are from equations $(10.1-10.3)$. The dependent variable is the ratio between Loan Loss Provisions on Bad Loans over Total Assets. $N P L_{i, t}$ is the ratio of Bad Loans to Total Loans. $\triangle N P L_{i, t}$ is the one period ahead first - difference of $N P L_{i, t} . L O A N_{i, t}$ is the ratio of Total Loans to Total Assets. $\triangle G D P_{t}$ is the annual growth of real GDP. CRISIS $S_{t}$ is a dummy variable that takes the value equal to 1

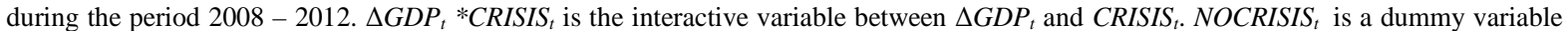
that takes the value equal to 1 during the period 2001 - 2007. $I S_{i, t}$ is the ratio of earnings before interest, taxes and loan loss provision to total assets. $L O C A L_{i, t}$ is a dummy variable that takes value 1 if the bank is a Local Bank and 0 otherwise. $L G U A_{i, t}$ is a dummy variable that takes value 1 if the bank has the ratio of guaranteed loans to total loans lower than the level associated to the 75th percentile of the sample distribution and 0 otherwise. $L G U A_{i, t} * I S_{i, t} * L O C A L_{i, t}$ is the interactive dummy between $L G U A_{i, t}$, IS $S_{i, t}$ and $L O C A L_{i, t}$.

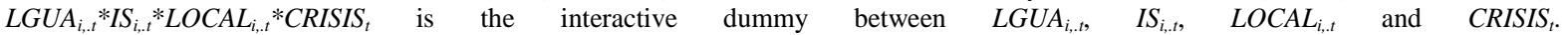
$L G U A_{i, t} * I S_{i, t} * L O C A L_{i, t} * N O C R I S I S_{t}$ is the interactive dummy between $L G U A_{i, t}, I S_{i, t}, L O C A L_{i, t}$ and $N O C R I S I S_{t}$. CAP $P_{i, t}$ is a dummy variable that takes value 1 if the bank has a Tier1 Ratio greater than the level associated to the 75th percentile of the sample distribution and 0 otherwise. Definition, sources, number of observations, and preliminary statistics are shown in Tables 1-4.

The regression method is the Arellano-Bond two-step estimator. *, ** and *** indicate statistically significance respectively at the $10 \%$, at $5 \%$ and at $1 \%$ level.

Source: Authors' calculations using data from by Istat and ABI (Italian Banking Association). 
Table 17. Results from equations (11) using $H C R_{i, t}$

\section{Dependent variable: $L L P_{i, t}$}

\begin{tabular}{|c|c|c|c|c|c|c|}
\hline \multirow{2}{*}{$\begin{array}{l}\text { Regressors } \\
\text { constant }\end{array}$} & \multicolumn{2}{|c|}{ Equation (11.1) } & \multicolumn{2}{|c|}{ Equation (11.2) } & \multicolumn{2}{|c|}{ Equation (11.3) } \\
\hline & -0.0089 & $* * *$ & -0.0090 & $* * *$ & -0.0088 & $* * *$ \\
\hline$L L P_{i, t-1}$ & -0.0455 & & -0.0457 & & -0.0458 & \\
\hline$N P L_{i, t}$ & 0.2486 & $* * *$ & 0.2460 & $* * *$ & 0.2483 & $* * *$ \\
\hline$\triangle N P L_{i, t}$ & 0.0072 & & 0.0078 & & 0.0074 & \\
\hline$L O A N_{i, t}$ & 0.0163 & $* * *$ & 0.0164 & $* * *$ & 0.0163 & $* * *$ \\
\hline$\Delta G D P_{t}$ & 0.0301 & $* * *$ & 0.0323 & $* * *$ & 0.0299 & $* * *$ \\
\hline CRISIS $_{t}$ & 0.0007 & $* * *$ & 0.0008 & $* * *$ & 0.0008 & $* * *$ \\
\hline$\Delta G D P_{t} * C^{2} I S I S_{t}$ & -0.0288 & $* * *$ & -0.0309 & $* * *$ & -0.0286 & $* * *$ \\
\hline$C A P_{i, t}$ & 0.0004 & * & 0.0004 & $*$ & 0.0004 & $*$ \\
\hline$H C R_{i, t} * I S_{i, t} * L O C A L_{i, t}$ & -0.0104 & & - & & - & \\
\hline $\operatorname{HCR}_{i, t} * I S_{i, t} * \operatorname{LOCAL}_{i, t} *$ CRISIS $_{t}$ & - & & 0.2540 & $*$ & - & \\
\hline HCR $_{i, t} * I S_{i, t} *$ LOCAL $_{i, t} *$ NOCRISIS $_{t}$ & - & & - & & -0.0118 & \\
\hline Observations & 4,328 & & 4,328 & & 4,328 & \\
\hline Interacted Dummies & Yes & & Yes & & Yes & \\
\hline$R^{2}$ & 0.8084 & & 0.8103 & & 0.8084 & \\
\hline \# instruments & 54 & & 54 & & 54 & \\
\hline VCE robust & Yes & & Yes & & Yes & \\
\hline AR(2) Test (p-value) & 0.4624 & & 0.3811 & & 0.4581 & \\
\hline Wald test (p-value) & 0.0000 & & 0.0000 & & 0.0000 & \\
\hline
\end{tabular}

Note. The results are from equations $(11.1-11.3)$. The dependent variable is the ratio between Loan Loss Provisions on Bad Loans over Total Assets. $N P L_{i, t}$ is the ratio of Bad Loans to Total Loans. $\triangle N P L_{i, t}$ is the one period ahead first - difference of $N P L_{i, t} . L O A N_{i, t}$ is the ratio of Total Loans to Total Assets. $\triangle G D P_{t}$ is the annual growth of real GDP. CRISIS $S_{t}$ is a dummy variable that takes the value equal to 1

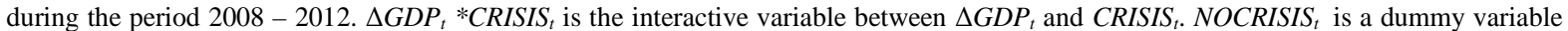
that takes the value equal to 1 during the period $2001-2007 . I S_{i, t}$ is the ratio of earnings before interest, taxes and loan loss provision to total assets. $L O C A L_{i, t}$ is a dummy variable that takes value 1 if the bank is a Local Bank and 0 otherwise. $H C R_{i, t}$ is a dummy variable that takes value 1 if the bank has a coverage ratio higher than the level associated to the 75th percentile of the sample distribution and 0 otherwise. $H C R_{i, t} * I S_{i, t} * L O C A L_{i, t}$ is the interactive dummy between $H C R_{i, t}$, IS $S_{i, t}$ and $L O C A L_{i, t} . H C R_{t} * I S_{i, t} * L O C A L_{i, t} * C R I S I S_{t}$ is the interactive dummy between $H C R_{t}, I S_{i, t}, L O C A L_{i, t}$ and $C R I S I S_{t} . H C R_{i, t}{ }^{*} I_{i, t}{ }^{*} L O C A L_{i, t} * N O C R I S I S_{t}$ is the interactive dummy between $H C R_{i, t}, I S_{i, t}, L O C A L_{i, t}$ and NOCRISIS . CAP $_{i, t}$ is a dummy variable that takes value 1 if the bank has a Tier1 Ratio greater than the level associated to the 75th percentile of the sample distribution and 0 otherwise. Definition, sources, number of observations, and preliminary statistics are shown in Tables 1-4.

The regression method is the Arellano-Bond two-step estimator. *, ** and *** indicate statistically significance respectively at the $10 \%$, at $5 \%$ and at $1 \%$ level.

Source: Authors' calculations using data from by Istat and ABI (Italian Banking Association). 
Table 18. Results from equations (11) using $L C R_{i, t}$

\section{Dependent variable: $L L P_{i, t}$}

\begin{tabular}{|c|c|c|c|c|c|c|}
\hline \multirow{2}{*}{$\begin{array}{l}\text { Regressors } \\
\text { constant }\end{array}$} & \multicolumn{2}{|c|}{ Equation 11.1} & \multicolumn{2}{|c|}{ Equation 11.2} & \multicolumn{2}{|c|}{ Equation 11.3} \\
\hline & -0.0088 & $* * *$ & -0.0087 & $* * *$ & -0.0090 & $* * *$ \\
\hline$L L P_{i, t-1}$ & -0.0545 & & -0.0412 & & -0.0469 & \\
\hline$N P L_{i, t}$ & 0.2463 & $* * *$ & 0.2447 & $* * *$ & 0.2482 & $* * *$ \\
\hline$\triangle N P L_{i, t}$ & 0.0056 & & 0.0042 & & 0.0070 & \\
\hline$L O A N_{i, t}$ & 0.0163 & $* * *$ & 0.0159 & $* * *$ & 0.0163 & $* * *$ \\
\hline$\Delta G D P_{t}$ & 0.0353 & $* * *$ & 0.0316 & $* * *$ & 0.0323 & $* * *$ \\
\hline CRISIS $_{t}$ & 0.0008 & $* * *$ & 0.0013 & $* * *$ & 0.0009 & $* * *$ \\
\hline$\Delta G D P_{t} * C R I S I S_{t}$ & -0.0341 & $* * *$ & -0.0301 & $* * *$ & -0.0310 & $* * *$ \\
\hline$C A P_{i, t}$ & 0.0005 & $*$ & 0.0004 & $*$ & 0.0004 & $*$ \\
\hline$L C R_{i, t} * I S_{i, t} * L O C A L_{i, t}$ & -0.0155 & & - & & - & \\
\hline$L_{C R} R_{i, t} * I_{i, t} * L O C A L_{i, t} *$ CRISIS $_{t}$ & - & & -0.0780 & $*$ & - & \\
\hline$L_{C R} R_{i, t} * I S_{i, t} * \operatorname{LOCAL}_{i, t} *$ NOCRISIS $_{t}$ & - & & - & & 0.0231 & \\
\hline Observations & 4,328 & & 4,328 & & 4,328 & \\
\hline Interacted Dummies & Yes & & Yes & & Yes & \\
\hline$R^{2}$ & 0.8039 & & 0.8113 & & 0.8078 & \\
\hline \# instruments & 54 & & 54 & & 54 & \\
\hline VCE robust & Yes & & Yes & & Yes & \\
\hline AR(2) Test (p-value) & 0.4485 & & 0.4087 & & 0.4591 & \\
\hline Wald test (p-value) & 0.0000 & & 0.0000 & & 0.0000 & \\
\hline
\end{tabular}

Note. The results are from equations $(11.1-11.3)$. The dependent variable is the ratio between Loan Loss Provisions on Bad Loans over Total Assets. $N P L_{i, t}$ is the ratio of Bad Loans to Total Loans. $\triangle N P L_{i, t}$ is the one period ahead first - difference of $N P L_{i, t} . L O A N_{i, t}$ is the ratio of Total Loans to Total Assets. $\triangle G D P_{t}$ is the annual growth of real GDP. CRISIS $S_{t}$ is a dummy variable that takes the value equal to 1

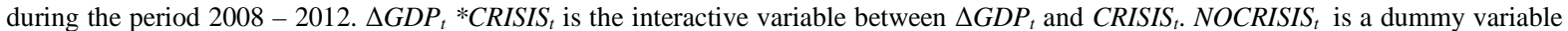
that takes the value equal to 1 during the period $2001-2007 . I S_{i, t}$ is the ratio of earnings before interest, taxes and loan loss provision to total assets. $L O C A L_{i, t}$ is a dummy variable that takes value 1 if the bank is a Local Bank and 0 otherwise. $L C R_{i, t}$ is a dummy variable that takes value 1 if the bank has a coverage ratio lower than the level associated to the 75th percentile of the sample distribution and 0 otherwise. $L C R_{i, t} * S_{i, t} * L O C A L_{i, t}$ is the interactive dummy between $L C R_{i, t}, I S_{i, t}$ and $L O C A L_{i, t .} . L C R_{i, t} * I S_{i, t} * L O C A L_{i, t} * C R I S I S_{t}$ is the interactive dummy between $L C R_{i, t}, I S_{i, t}, L O C A L_{i, t}$ and $C R I S I S_{t} . L C R_{i, t} * I S_{i, t} * L O C A L_{i, t} * N O C R I S I S_{t}$ is the interactive dummy between $L C R_{i, t}, I S_{i, t}, L O C A L_{i, t}$ and NOCRISIS . CAP $P_{i, t}$ is a dummy variable that takes value 1 if the bank has a Tier1 Ratio greater than the level associated to the 75th percentile of the sample distribution and 0 otherwise. Definition, sources, number of observations, and preliminary statistics are shown in Tables 1-4.

The regression method is the Arellano-Bond two-step estimator. *, ** and *** indicate statistically significance respectively at the $10 \%$, at $5 \%$ and at $1 \%$ level.

Source: Authors' calculations using data from by Istat and ABI (Italian Banking Association). 
Table 19. Results from equations (12) using HRISK ${ }_{i, t}$

\section{Dependent variable: $L L P_{i, t}$}

\begin{tabular}{|c|c|c|c|c|c|c|}
\hline \multirow{2}{*}{$\begin{array}{l}\text { Regressors } \\
\text { constant }\end{array}$} & \multicolumn{2}{|c|}{ Equation (12.1) } & \multicolumn{2}{|c|}{ Equation (12.2) } & \multicolumn{2}{|c|}{ Equation (12.3) } \\
\hline & -0.0091 & $* * *$ & -0.0084 & $* * *$ & -0.0090 & $* * *$ \\
\hline$L L P_{i, t-1}$ & -0.0418 & & -0.0408 & & -0.0451 & \\
\hline$N P L_{i, t}$ & 0.2467 & $* * *$ & 0.2445 & $* * *$ & 0.2477 & $* * *$ \\
\hline$\triangle N P L_{i, t}$ & 0.0071 & & 0.0063 & & 0.0072 & \\
\hline$L O A N_{i, t}$ & 0.0167 & $* * *$ & 0.0154 & $* * *$ & 0.0163 & $* * *$ \\
\hline$\Delta G D P_{t}$ & 0.0302 & $* * *$ & 0.0312 & $* * *$ & 0.0317 & $* * *$ \\
\hline CRISIS $_{t}$ & 0.0007 & $* * *$ & 0.0011 & $* * *$ & 0.0008 & $* * *$ \\
\hline$\Delta G D P_{t} * C R I S I S_{t}$ & -0.0293 & $* * *$ & -0.0303 & $* * *$ & -0.0304 & $* * *$ \\
\hline$C A P_{i, t}$ & 0.0004 & $*$ & 0.0004 & $*$ & 0.0004 & $*$ \\
\hline $\operatorname{HRISK}_{i, t} * I S_{i, t} * \operatorname{LOCAL}_{i, t}$ & -0.0534 & $* * *$ & - & & - & \\
\hline HRISK $_{i, t} * I S_{i, t} *$ LOCAL $_{i, t} *$ CRISIS $_{t}$ & - & & -0.0990 & $* * *$ & - & \\
\hline HRISK $_{i, t} * \operatorname{IS}_{i, t} * \operatorname{LOCAL}_{i, t} *$ NOCRISIS $_{t}$ & - & & - & & -0.0026 & \\
\hline Observations & 4,328 & & 4,328 & & 4,328 & \\
\hline Interacted Dummies & Yes & & Yes & & Yes & \\
\hline$R^{2}$ & 0.8099 & & 0.8115 & & 0.8084 & \\
\hline \# instruments & 54 & & 54 & & 54 & \\
\hline VCE robust & Yes & & Yes & & Yes & \\
\hline AR(2) Test (p-value) & 0.4645 & & 0.4154 & & 0.4518 & \\
\hline Wald test ( $p$-value) & 0.0000 & & 0.0000 & & 0.0000 & \\
\hline
\end{tabular}

Note. The results are from equations $(12.1$ - 12.3). The dependent variable is the ratio between Loan Loss Provisions on Bad Loans over Total Assets. $N P L_{i, t}$ is the ratio of Bad Loans to Total Loans. $\triangle N P L_{i, t}$ is the one period ahead first - difference of $N P L_{i, t} . L O A N_{i, t}$ is the ratio of Total Loans to Total Assets. $\triangle G D P_{t}$ is the annual growth of real GDP. CRISIS $S_{t}$ is a dummy variable that takes the value equal to 1

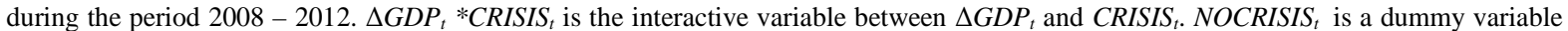
that takes the value equal to 1 during the period $2001-2007 . I S_{i, t}$ is the ratio of earnings before interest, taxes and loan loss provision to total assets. $L O C A L_{i, t}$ is a dummy variable that takes value 1 if the bank is a Local Bank and 0 otherwise. RISK $K_{i, t}$ is the standard deviation of adjusted Return on Equity, computed using 3-year rolling windows. HRISK $K_{i, t}$ is a dummy variable which takes value of 1 if $R I S K_{i, t}$ for the ith bank is greater than the value associated to the $75^{\text {th }}$ percentile of the sample distribution and 0 otherwise. $H R I S K_{i, t} * I S_{i, t} * L O C A L_{i, t}$ is the interactive dummy between $H_{R I S K} K_{i, t}, S_{i, t}$ and $L O C A L_{i, t} . H_{R I S K}{ }_{i, t}{ }^{*} I_{i, t}{ }^{*} L O C A L_{i, t} *{ }^{*} R I S I S_{t}$ is the interactive dummy between $H R I S K_{i, t}$, IS $S_{i, t}$,

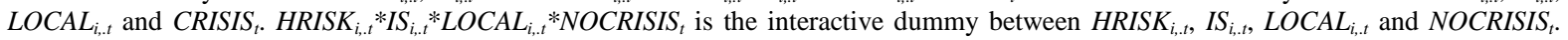
$C A P_{i, t}$ is a dummy variable that takes value 1 if the bank has a Tier1 Ratio greater than the level associated to the 75th percentile of the sample distribution and 0 otherwise. Definition, sources, number of observations, and preliminary statistics are shown in Tables 1-4.

The regression method is the Arellano-Bond two-step estimator. *, ** and *** indicate statistically significance respectively at the $10 \%$, at $5 \%$ and at $1 \%$ level.

Source: Authors' calculations using data from by Istat and ABI (Italian Banking Association). 
Table 20. Results from equations (12) using LRISK $K_{i, t}$

\section{Dependent variable: $L L P_{i, t}$}

\begin{tabular}{|c|c|c|c|c|c|c|}
\hline \multirow{2}{*}{$\begin{array}{l}\text { Regressors } \\
\text { constant }\end{array}$} & \multicolumn{2}{|c|}{ Equation (12.1) } & \multicolumn{2}{|c|}{ Equation (12.2) } & \multicolumn{2}{|c|}{ Equation (12.3) } \\
\hline & -0.0087 & $* * *$ & -0.0091 & $* * *$ & -0.0092 & $* * *$ \\
\hline$L L P_{i, t-1}$ & -0.0469 & & -0.0453 & & -0.0450 & \\
\hline$N P L_{i, t}$ & 0.2470 & $* * *$ & 0.2488 & $* * *$ & 0.2484 & $* * *$ \\
\hline$\Delta N P L_{i, t}$ & 0.0061 & & 0.0067 & & 0.0074 & \\
\hline$L O A N_{i, t}$ & 0.0161 & $* * *$ & 0.0164 & $* * *$ & 0.0165 & $* * *$ \\
\hline$\Delta G D P_{t}$ & 0.0326 & $* * *$ & 0.0318 & $* * *$ & 0.0313 & $* * *$ \\
\hline CRISIS $_{t}$ & 0.0008 & $* * *$ & 0.0009 & $* * *$ & 0.0009 & $* * *$ \\
\hline$\Delta G D P_{t} * C R I S I S_{t}$ & -0.0314 & $* * *$ & -0.0305 & $* * *$ & -0.0300 & $* * *$ \\
\hline$C A P_{i, t}$ & 0.0005 & $*$ & 0.0004 & $*$ & 0.0004 & $*$ \\
\hline $\operatorname{LRISK}_{i, t} * \operatorname{IS}_{i, t} * \operatorname{LOCAL}_{i, t}$ & -0.0224 & & - & & - & \\
\hline LRISK $_{i, t} * I_{i, t} * L_{O C A L_{i, t}} *$ CRISIS $_{t}$ & - & & -0.0051 & & - & \\
\hline $\operatorname{LRISK}_{i, t} * I_{i, t} * \operatorname{LOCAL}_{i, t} *$ NOCRISIS $_{t}$ & - & & - & & 0.0214 & $*$ \\
\hline Observations & 4328 & & 4328 & & 4328 & \\
\hline Interacted Dummies & Yes & & Yes & & Yes & \\
\hline$R^{2}$ & 0.8062 & & 0.8083 & & 0.8080 & \\
\hline \# instruments & 54 & & 54 & & 54 & \\
\hline VCE robust & Yes & & Yes & & Yes & \\
\hline AR(2) Test (p-value) & 0.4632 & & 0.4552 & & 0.4481 & \\
\hline Wald test (p-value) & 0.0000 & & 0.0000 & & 0.0000 & \\
\hline
\end{tabular}

Note. The results are from equations $(12.1$ - 12.3). The dependent variable is the ratio between Loan Loss Provisions on Bad Loans over Total Assets. $N P L_{i, t}$ is the ratio of Bad Loans to Total Loans. $\triangle N P L_{i, t}$ is the one period ahead first - difference of $N P L_{i, t} . L O A N_{i, t}$ is the ratio of Total Loans to Total Assets. $\triangle G D P_{t}$ is the annual growth of real GDP. CRISIS $S_{t}$ is a dummy variable that takes the value equal to 1

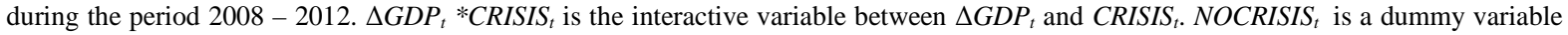
that takes the value equal to 1 during the period $2001-2007 . I S_{i, t}$ is the ratio of earnings before interest, taxes and loan loss provision to total assets. $L O C A L_{i, t}$ is a dummy variable that takes value 1 if the bank is a Local Bank and 0 otherwise. RISK $K_{i, t}$ is the standard deviation of adjusted Return on Equity, computed using 3-year rolling windows. $L R I S K_{i, t}$ is a dummy variable which takes value of 1 if $R I S K_{i, t}$ for the ith bank is lower than the value associated to the $75^{\text {th }}$ percentile of the sample distribution and 0 otherwise. $L R I S K_{i, t} * I S_{i, t} * L O C A L_{i, t}$ is the interactive dummy between $L R I S K_{i, t}, I S_{i, t}$ and $L O C A L_{i, t} . L_{R I S K_{i, t}}{ }^{*} S_{i, t}{ }^{*} L O C A L_{i, t}{ }^{*} C R I S I S_{t}$ is the interactive dummy between $L R I S K_{i, t}, I S_{i, t}$, LOCAL $_{i, t}$ and CRISIS $S_{t}$ LRISK $_{i, t} * I_{i, t}{ }^{*}$ LOCAL $_{i, t} * N O C R I S I S_{t}$ is the interactive dummy between LRISK $_{i, t,}$, IS $_{i, t,}$, LOCAL $_{i, t}$ and NOCRISIS . $^{*}$ $C A P_{i, t}$ is a dummy variable that takes value 1 if the bank has a Tier1 Ratio greater than the level associated to the 75 th percentile of the sample distribution and 0 otherwise. Definition, sources, number of observations, and preliminary statistics are shown in Tables 1-4.

The regression method is the Arellano-Bond two-step estimator. *, ** and *** indicate statistically significance respectively at the $10 \%$, at $5 \%$ and at $1 \%$ level.

Source: Authors' calculations using data from by Istat and ABI (Italian Banking Association). 